\title{
THE DIRECTION OF EDUCATIONAL REFORMS AND CHALLENGES FOR SUSTAINABLE DEVELOPMENT IN FINNISH EDUCATION
}

\begin{abstract}
The article reveals the elements of education for sustainable development in the Finnish education undergoing a reform. The reform movement in the Finnish education, incompatible with the global educational reform model, has laid the foundations for an effective education system with pedagogical principles fitting into the challenges of sustainable development. Finnish education following its own strategy of educational reforms has led to the smallest differences between the results of PISA tests among students in the world.
\end{abstract}

Keywords: a goal-oriented policy; sustainability; sustainable education; sustainable future; multi-professional cooperation.

\section{Introduction}

The Finns have built a goal-oriented policy of sustainable development which promotes not only the climate of lifelong learning, but contributes to the rapid development of knowledge and skills indispensable for employees in the 21st century. Sustainable development in education was incorporated into real life school situations. Consequently, "Finland's successful performance in OECD's PISA has contributed to its iconic status and position of an educational leader in the world." (Suwalska, 2017a, p. 69)

There have been only a few educational reforms since 1963 in Finnish education that could be termed structural. There is a visible gradual process of reforms that are based on longer-term vision of education. Reforms are incorporated into sustainable goals of education. Until 1990s the government still had an influence on the management of education. The centralized tendency has been exchanged into decentralized according to the social and political transformation of the mid-199os. 
The change in education in Finland enables municipalities and other public services to be autonomous in the process of planning education.

Since the 1990s The Ministry of Education has been responsible for education policy, the legislation process and funding. The National Board of Education participates in curriculum development, the ways education is evaluated and it helps professionally not only schools but also teachers. As a result, the quality of education depends on local leadership and management which are the key stakeholders in education development and monitoring. Moreover, local authorities are financially responsible for their school decisions. Consequently, the highest level of education is directly tied to the quality of management and leadership skills. It is seen in the 2018 Worldwide Educating For the Future index where Finland is an undisputed leader.

Table 1. Worldwide Educating For the Future index

\begin{tabular}{|c|l|c|c|c|c|}
\hline Place & Economy & Overall Score & $\begin{array}{l}\text { Policy } \\
\text { Environment }\end{array}$ & $\begin{array}{l}\text { Teaching } \\
\text { Environment }\end{array}$ & $\begin{array}{l}\text { Socio-Economic } \\
\text { Environment }\end{array}$ \\
\hline $1^{\text {st }}$ & Finland & 80,9 & 96,7 & 67,6 & 90,6 \\
\hline $2^{\text {nd }}$ & Switzerland & 80,3 & 93,6 & 69,5 & 87,6 \\
\hline $3^{\text {rd }}$ & New Zealand & 79,3 & 88,2 & 69,7 & 90,1 \\
\hline $4^{\text {th }}$ & Sweden & 78,1 & 89,5 & 66,5 & 89,8 \\
\hline $5^{\text {th }}$ & Canada & 77,9 & 76,5 & 74,5 & 88,3 \\
\hline $25^{\text {th }}$ & Ghana & 53,9 & 71,4 & 42,7 & 55,5 \\
\hline $26^{\text {th }}$ & Russia & 52,9 & 60,7 & 53,3 & 40 \\
\hline $27^{\text {th }}$ & Poland & 52,5 & 41,9 & 55,2 & 61,9 \\
\hline
\end{tabular}

Source: Worldwide Educating For the Future Index, Building tomorrow's global citizens, 2018, p. 6.

This report reveals that Finland has the highest score in the world both in the socio-economic, and policy environments. Moreover, this country had the third position in the teaching environment. I claim that successful policymakers are responsible for leading a sustainable course of the Finnish schools. Furthermore, Finns have identified the skills their students are going to need. Finland together with Canada, Chile, New Zealand, Singapore and Sweden achieved the best scores in the world.

Unfortunately, Poland is placed 27th in this report. Ghana and Russia, which had 25th and 26th places respectively, have created a better policy environment for education. However, Poland had better results in Socio-Economic Environment and Teaching Environment than Ghana and Russia. As a result of this study, we see the need for a continuous evaluation of education due to rapid changes in the contemporary society and global job markets.

Moreover, teachers are obliged to follow educational changes and be able to incorporate them into their teaching. Furthermore, preparing students for external exams does not support future-oriented teaching and sustainable 
development in education. It does not benefit pupils who should be developing their abilities to solve problems, collaborate and be creative. Schools that put their focus on testing have a negative impact on students and their future. They also negatively affect students' families.

\section{Mission of Basic Education since 2014}

Basic Education with pre-primary education build the foundations for general knowledge and skills needed to finish the mandatory education in Finland. It is a required step before students are allowed to be admitted to the upper-secondary education. It helps strengthen students' personal skills and build a sustainable future for each student. Its mission takes into account educational, social, cultural and future-related perspectives. Education is to support students' "learning, development and well-being in cooperation with the homes." (National Core Curriculum for Basic Education, 2014, p. 19) It makes sense to mention many-sided development of students' own competences. Basic Education promotes a sustainable lifestyle so that students can grow to become part of society. Moreover, it teaches students to respect and protect human rights.

The social task of Basic Education is to build the social capital of students, to reinforce equality, equity and social justice. In this light it is indispensable to mention about preventing inequality and any kinds of exclusion to support gender equality in Finland. The main mission of Basic Education is to encourage girls and boys to study all school subjects equally with the understanding of the gender differences. Moreover, teachers recognize different skills their students may possess, but they do not include "role models determined by gender." (National Core Curriculum for Basic Education, 2014, p. 19)

Basic Education promotes cultural diversity and shows how to appreciate the heritage of multicultural world. In this light, students build up their cultural identities and understand different cultures on the continuum of the cultural evolution. As a result, students are able to share their opinions about the future of Finland and the whole world. Moreover, they develop the needed skills to live in the changing world and be a part of a sustainable future. Students are encouraged to lead sustainable lives and treat people equally. They understand political proposals of different political parties.

\section{Practical organization of school work}

The organization of each school day involves concept of learning rooted in school culture and the underlying set of values. As a result, Finnish school set conditions to promote students' well-being with a constant development and learning.

Moreover, the best school practice contributes to the promotion of a sustainable way of life and to a shared responsibility for students' safety at schools. Students' 
needs, skills and strengths are taken into account to promote good education in schools. "Each pupil is entitled to instruction, guidance, pupil welfare and support according to the curriculum on all school days and a safe learning environment." (Section 30 [1] and 229 [1] of the Basic Education Act, 2013).

The school head is responsible for all safety issues. Moreover, the school manager is responsible for well-balanced school instructions, students' guidance and the appropriate level of school support in all subjects. School teachers select teaching methods and methods to lead school activities for students.

\section{The term 'sustainability' - literature review}

The actual context of the idea of sustainability was first used at the beginning of the 18th century in the field of forestry and mining. It gained its contemporary meaning due to the Hans Carl von Carlowitz insight ,that there will always be enough wood as long as you do not cut more than in the same time will grow. Actually Carlowitz did not use the term sustainability, but sustainable use."

The definition of sustainable development first appeared in the Brundtland Commission Report, the World Commission on Environment and Development, Our Common Future in 1987: "Sustainable development is the development that satisfies the needs of the present population without endangering the possibilities of future generations to satisfy their needs [...] thus the goals of economic and social development must be defined in terms of sustainability in all countries. Interpretations will vary but they must share certain general features and must be compatible with the basic concept of sustainable development." (Report of the World Commission on Environment and Development: Our Common Future, p. 54) Sustainable development has been widely used in politics since the UNCED Conference on Environment and Development held in Rio de Janeiro in 1992.

After the "2030 Agenda for Sustainable Development" was developed the 17 Sustainable Development Goals (SDGs) have become "the global consensus". After more than twenty years of discussions on what Education for Sustainable Development is, an international consensus was reached to include eight competencies which were published by UNESCO in 2017:

1. "Systems thinking competence - the ability to recognize and understand relationships;

2. Anticipatory competence: the ability to understand and engage with multiple futures - possible, probable and desirable;

3. Normative competence: the ability to understand and reflect on the norms and values;

4. Strategic competence: the ability to collectively develop and implement innovative actions;

5. Collaboration competence: the ability to learn from others; to understand and respect the needs; 
6. Critical thinking competence: the ability to question norms, practices and opinions;

7. Self-awareness competence: the ability to reflect on one's own role in the local community and (global) society;

8. Integrated problem-solving competence: the overreaching ability to apply different problem-solving frameworks to complex sustainability problems" (Hoffmann et al, 2017, p. 5).

The US National Academy of Sciences underlined the transition direction in its milestone report, "Our Common Journey: A Transition Towards Sustainability" (Kates, 1999, pp. 1-35). Firstly, Finland could improve the equity and equal educational opportunities for gifted and talented children. Moreover, the Finnish government should support ecosystems by ensuring a constant improvement of economy and the levels of country's consumption. I claim that Finnish authorities understand global changes well and are capable of incorporating slow changes into schools, too.

Sustainability has been present in the Basic Education Policy Documents in in Finland since 1985. Core curriculum described "the environment and nature protection" (Finnish National Board of Education, 1985) as its main goals.

Sustainable future in the 2014 National Core Curriculum for Basic Education is presented in three different ways. It is specified as sustainable lifestyle, sustainable development, and sustainability. In Underlying values of basic education (p. 16) we accept the "necessity of a sustainable way of living", where "sustainable development and ways of living comprise an ecological and economic dimension as well as a social and cultural dimension. [...] Eco-social knowledge and ability means that pupils understand the seriousness of climate change, in particular, and strive for sustainability.” (National Core Curriculum for Basic Education, 2014, p. 6)

In the same document, in the section on cultural diversity we read that „basic education is built on a diverse Finnish cultural heritage. It has been being shaped in an interaction between different cultures. Education supports the pupils in building their personal cultural identity. [...] It reinforces creativity and respect for cultural diversity and promotes interaction within and between cultures." (National Core Curriculum for Basic Education, 2014, p. 16)

\section{School principals in the light of sustainable education in Finland}

Sustainable development in education was incorporated into real life school situations in Finland. From the 1990s the school principals are not only the educational leaders in their schools, but they are also managers who are responsible for finances of schools and academic results. School principals are obliged to be qualified leaders who are able to incorporate educational changes into schools and to have abilities to manage it well. Moreover, the requirements for leaders' postisions include experience in teaching and passing psychological tests to prove their competences. 
The vision-driven development of education is based on sustainable development, too. It enables schools and municipalities to pay attention to the process of teaching and learning. In this light, it makes sense to mention that it is almost impossible for schools to perform well right after reforms are put into force. The school transformation into a learning and creative organization requires learning from other schools. Since 199os in Finland a process of wide recognition of school culture has been visible. Long and sustainable changes in education had to be introduced.

\section{Building a sustainable future - the dimension of National Core Curriculum for Basic Education 2014}

Many European countries seem in need to teach competences that enable their citizens to be the part of a globalized world. In 2014 these competences were named in Finland transversal competences. They refer to skills, knowledge and manner which are useful for students. (National Core Curriculum for Basic Education, 2014, p. 21)

The values present in Finnish schools create conditions conducive to improvement of transversal competences. They include: "Thinking skills and learning to learn, taking care of oneself and others, managing daily activities, safety, cultural competence, interaction and self-expression, multiliteracy, ICT-competence, working life and entrepreneurial competence, participation, involvement and building a sustainable future." (National Core Curriculum for Basic Education, 2014, pp. 21-25) Building a sustainable future is based on transversal competences and on other prerequisites. Basic education which creates the school environment and contributes to "pupils' growth into active citizens who use democratic rights and freedom responsibility." (National Core Curriculum for Basic Education, 2014, p. 25)

Pupils in basic education are involved in the school and local communities. Moreover, schools are obliged to respect students' rights to make decisions adequate to their age and development. Basic schools help students plan, implement, assess and evaluate their learning in a particular learning environment. As a result, students are taught how to be active citizens of society and the local community. Students understand a need for environmental protection and are able to build up their personal relationship with surrounding environment. Moreover, they are able to understand the impact of media on their lives and to use its potential.

On the other hand, Finnish students learn the importance of rules and regulations that govern their lives. Furthermore, they learn to work with others, practise negotiation skills, "arbitration and conflict resolution as well as critical examination of issues." (National Core Curriculum for Basic Education, 2014, p. 25)

\section{Multi-Professional Cooperation}

The National Board of Education and University of Tampere participated in the sustainable project about cooperative school development. 15 local schools, 
located around university, participated in the "The School Community: Crossing Boundaries towards Multi-Professional Cooperation" project to integrate pre-service and in-service teachers education with school communities. This project is an example of how Finns lead an active and sustainable dialogue between all partners in school community, local authorities and the academics to support multi-professional ideas and implement them in sustainable real school life.

The main aim of the project was a promotion of the inclusive working culture to build up everyday life activities in Finnish schools. The second main reason was to "strengthen multi-professional collaboration in schools." (Niemi, 2015, p. 286) The third goal was to link together teachers' work with sustainable development in context of guidance and counselling in Finnish schools.

According to the National Board of Education "in the case of Guidance Goals for Youths, there is a big emphasis on self-knowledge strengths and areas of development, life-long education and career choice-making. Moreover, the need to improve abilities of being a part of group or community is seen, as well as the ability for further studies and working-life. As a result, students are able to develop professional identity, design life and career paths." (Suwalska, 2017b, p. 75)

Rajakaltio (2014) recommends that "pedagogical leadership and principals' commitment in the project are keystones for successful development." Furthermore, leadership and the whole community are obliged to participate fully in the project. The project work must be connected to the city's planning for sustainable development and to municipality's vision of sustainable development. According to Niemi (2015, p. 287): "schools need a multi-professional cooperation, learnercenteredness, networking with in-school communities and with partners outside of schools, and the long-lasting development work."

As a result, the project revealed the importance of teachers' work in the development of schools. As a consequence, each school has built a cooperative school culture to overcome obstacles of everyday life and to tap into the contemporary challenges. Innovative School Community described by Niemi was introduced in Finland in 2012-2014. The Innovative School Community (ISC) represents the holistic model of school which supports not only teaching but also learning. Technology was widely used to enable cooperation in schools. Common mobile devices and iPads were used in this project. In this school teachers working with researchers contributed to the creation of school culture. Techers, who worked in groups, were working with students, too. According to main goals of the project students and teachers were main actors of innovations. They planned, implemented and develop activities based on technology and innovation within school.

Teachers, who worked in this project, were especially interested in increasing their technological skills. Moreover, they got to know how to collaborate with each other and use problem-solving skills. Furthermore, they acquired new and useful teaching methods to lead such projects in the future. Teachers improved managerial skills to be successful project leaders. They were prepared to lead international 
networks of teachers to conduct projects. Teachers and students, school principals and parents were able to cooperate with one another; they were able to be active learners in this learning environment.

\section{Luma Center in the University of Helsinki}

The academics at the Helsinki University were interested in increasing students' motivation to study math and science. They prepared plans for the Luma Center to enable students to study science, technology and math (STEM). The Luma Center was established to introduce social innovations for universities, schools, teachers, and students (Aksela, 2014).

It strengthens the relationship between students and teachers. Moreover, Luma Center supports teachers in lifelong learning and offer in-service training to new teachers.

Activities offered in the Luma Center were parts of training for elementary school teachers and subject teachers in seconadary schools. Moreover, pre-service teaching helps teachers prepare teaching materials and new, innovative ideas to work better. The Luma Center reinforces STEM education and STEM laboratories to use the latest materials of teaching. All in all, it makes sense to mention that participation in the project influences on lifelong-learning of teachers. Techers are able to conduct small educational projects with the support of STEM guidance. They can design their own activities which are related to the creation of technological environments and their own school curriculum.

\section{Conclusion}

The comparative pedagogy (education) helps us not only understand the educational changes, but first of all teaches us how to implement them in the Polish educational reality. The main tasks of sustainable development have been written in the provisions of the Constitution of Poland. "The Republic of Poland shall safeguard the independence and integrity of its territory and ensure the freedoms and rights of persons and citizens, the security of the citizens, safeguard the national heritage and shall ensure the protection of the natural environment pursuant to the principles of sustainable development." (The Constitution of the Republic of Poland, chapter I, article 5)

Moreover, the 2030 Agenda for Sustainable Development - Implementation in Poland suggests that "Sustainable development is characterized by intergenerational solidarity aimed at finding solutions for guaranteeing further economic growth that actively includes all social groups in the development processes." On the other hand, there is no mention about sustainable development in the 2017 Maths School Curriculum (Dziennik Ustaw, pp. 160-174), Biology and Geography School 
Curriculum 2017 in Poland (Dziennik Ustaw, pp. 116-143). It means that the idea of sustainable development is not widely used in the Polish educational system.

When analysing steps of the successful educational reforms in Finland we noticed how significant cooperation between teachers and institutions is, which builds relationships to take a collective responsibility for the curriculum development and children's learning in the perspective of sustainable development. It makes sustainable development possible. Sustainable development, good environment and continuous improvement of quality are the instruments promoting peoples' good life. Moreover, there is also a need, as it is seen in Finland, to choose the best school graduates for the teaching profession. To sum up, schools are obliged to follow their educational aims and honour traditional pedagogical values based on creating relationships with pupils to support the targets of sustainable development.

\section{References}

Aksela, M, (2008). The Finnish LUMA Centre: Supporting teachers and students in science, mathematics, and technology for life-long learning. Lifelong Learning in Europe, 13, 70-72.

Finnish National Board of Education. Grunderna för grundskolans läroplan (National Core Curriculum for Basic Education. National Board of Education: Helsinki, Finland, 1985.

Finnish National Board of Education. Grunderna för grundskolans läroplan (National Core Currriculum for Basic Education). National Board of Education: Helsinki, Finland, 1994.

Finnish National Board of Education, Basic Education Act (Section 30(1) and 229(1) of (1267/2013), in Raising the achievement of all learners in inclusive education. Retrieved from: https://www.europeanagency.org/sites/default/files/agencyprojects/RaisingAchievement/CountryReports/Raising\%2oAchievement\%20 Finland\%20Country\%2oReport.pdf, (access date 03.09.19).

Finnish National Board of Education. Basic Education Decree (852/1998), 8, 10 and $11 \S$, Pupil and Student Welfare Act (1287/2013).

Hoffmann, T., \& Siege, H., What is Education for Sustainable Development (ESD)? Retrieved from: http://www.esd-expert.net/files/ESD-Expert/pdf/Was_wir_ tun/Lehr-\%2ound\%2oLernmaterialien/What_is_Education_for_Sustainable_ Development.pdf, 2017 (20.07.2019).

National Core Curriculum for Basic Education (2014). Finnish National Agency for Education. Juvenes Print.

Niemi, H. (2015). Teacher professional development in Finland: Towards a more holistic approach. Society and Education, 7(3), 278-294.

Kates, R. W. (1999). Our Common Journey. A transition Toward Sustainability. National Academy Press. Retrieved from: http://rwkates.org/pdfs/b1999.o1.pdf (03.09.19). 
OECD (2013), A Teachers' Guide to TALIS 2013: Teaching and Learning International Survey. Retrieved from: http://dx.doi.org/10.1787/9789264216075-en (03.09.19).

Podstawa programowa kształcenia ogólnego z komentarzem, szkoła podstawowa - matematyka. MEN. Retrieved from: file://C:/Users/lenovo/Desktop/Z\%20 pilpitu/Education\%2 ofor\%2osustainable\%2odevelopemnt\%20in\%20Poland/ matematyka.-pp-z-komentarzem.-szkola-podstawowa-1.pdf (o2.11.2019).

The Constitution of the Republic of Poland (1997). Retrieved from: https://www. sejm.gov.pl/prawo/konst/angielski/kon1.htm (03.11.19).

Rajakaltio, H. (2014). Towards renewing school. The action model of the school development - Integrating in-service-training and the development process. Reports and reviews. Helsinki. The Finnish National Board of Education.

Schwille, J., \& Dembélé, M. (2007). Global Perspectives on Teacher Learning: Improving Policy and Practice. International Institute for Educational Planning. Paris: UNESCO.

Stoll, L., Bolam, R., McMahon, A., Wallace, M. \& Thomas, S. (2006). Professional learning communities: A review of the literature. Journal of Educational Change, 7, 221-258.

Suwalska, A., (2017a). English Educational policy. Contemporary Challenges in a Historical-Comparative Context. Łodź-Kraków: Wydawnictwo Uniwersytetu Łódzkiego, Wydawnictow Uniwersytetu Jagiellońskiego.

Suwalska, A., (2017b), Lifelong Guidance in Finnish Education in the context of globalization. Studia Pedagogiczne, 50, 69-8o.

UNCED. Agenda 21: Programme of action for Sustainable Development: Rio Declaration on Environment and Development; Statement of Forest Principles: The Final Text of Agreements Negotiated by Governments at United Nations Conference on Environment and Development (UNCED), 3-14 June 1992, Rio de Janeiro, Brazil; United Nations Department of Public Information: New York, NY, USA, 1993.

Wolff, L.A., Sjöblom, P., Hofman-Bergholm, M., \& Palmberg, I., (2017). High Performance Education Fails in Sustainability? A Reflection on Finnish Primary Teacher Education. Education Sciences, 7, 22.

Worldwide Educating for the Future Index 2018, Building tomorrow's global citizens.Retrieved from: https:/educatingforthefuture.economist.com/ EIUYidanPrizeEducatingFortheFuture2018WP.pdf?fbclid=IwAR1S8woDOJte 7aGwY2sZoLBzRyyDFLZZeRA2fTcBSHVMVoVXQyQmGn4lJk (2403.2019).

\section{KIERUNKI WYZWAŃ I REFORM EDUKACYJNYCH DLA ZRÓWNOWAŻONEGO ROZWOJU W EDUKACJI FIŃSKIEJ}

Streszczenie: W artykule zaprezentowano składowe edukacji dla zrównoważonego rozwoju w kontekście reformowania edukacji fińskiej. Ruch reform w tym kraju jest rozbieżny 
wobec modelu globalnej reformy edukacyjnej. Finowie kierując się własną strategią reform edukacyjnych, osiągają od lat najlepsze wyniki na świecie w badaniach PISA.

Słowa kluczowe: polityka; zrównoważony rozwój; zrównoważona edukacja; zrównoważona przyszłość; współpraca wielozawodowa.

Arleta Suwalska - magister filologii angielskiej (2006), magister dydaktyki języków obcych, doktor nauk społecznych w dyscyplinie pedagogika (2014). Zatrudniona na Wydziale Nauk o Wychowaniu Uniwersytetu Łódzkiego. Autorka monografii pt. English Educational policy: Contemporary Challenges in a Historical-Comparative Context (2017) i serii artykułów o edukacji fińskiej. Adres do korespondencji: ul. Pomorska 46/48, 91-408 Łódź. Adres e-mailowy: arletasuwalska@o2.pl. 

ALEKSANDRA KULPA-PUCZYŃSKA

Forum Pedagogiczne

Wydział Nauk Pedagogicznych

9 (2019) 2, cz. 2

Uniwersytet Kardynała Stefana Wyszyńskiego

Wpłynęło: 04.10.2019

Warszawa

ORCID ID: http://orcid.org/ooo-0oo2-5440-3310

Zatwierdzono do druku: 20.11.2019

DOI: $10.21697 / \mathrm{fp} .2019 .2 .44$

\title{
FEATURES OF 'NEW' STUDENTS AND THE POTENTIAL OF FUTURE TEACHERS: FIRST EFFECTS OF “THE UNTEACHABLES” INTERNATIONAL PROJECT
}

\begin{abstract}
"Learn from them and you will see the new culture of high-performance work, the twenty-first-century school and college, the innovative corporation, a more open family, a democracy where citizens are engaged, and perhaps even the new, networked society."
\end{abstract}

(Tapscott 2009, p. 8)

\begin{abstract}
The problem of students with difficulties in functioning in a school environment is nowadays becoming significant, as the environment often does not respond to unique and complex needs of young learners, such as modern ways of exchanging experience and knowledge, or the possibility of active participation in the community of learners and support networks. This state of affairs dictates the need to create new educational resources (also developed in of cooperation of the academic community with secondary school teachers, or the cooperation of experts and practitioners from various countries) for future teachers who may face, for example, the problem of "burnt-out" young students. The main purpose of this paper is to share the first research results and reflections concerning the implementation of "The Unteachables" Erasmus+ project at the Faculty of Education and the Faculty of Biology and Environmental Sciences at the Cardinal Stefan Wyszynski University in Warsaw (in cooperation with partners from Denmark - project coordinator, Iceland, Spain, Slovenia and Italy).
\end{abstract}

Keywords: 'new' students; future teachers; secondary schools; universities; cooperation; the Erasmus+ Project. 


\section{Introduction}

The presented article is based, among others on experiences and selected research results concerning "The Unteachables" innovative Erasmus+ project. One of its goals (and related problems) is to investigate to what extent the growing percentage of young reluctant learners in Europe can be transformed into a group of students capable of setting the course of the education process, who are also ready to co-decide, e.g. on goals and the use of educational methods or tools. So far, the project has identified profiles of the surveyed youth - paying attention not only to the shortcomings, but primarily to the strengths and potential of "new" unteachable young students (which is also the subject of analysis in this study) - as well as the didactic challenges emerging from the profiles.

We are talking about teaching and learning strategies, also included in the prepared guide in the form of the Learnable Platform (void of "rigid" guidelines), and their use in scheduled teaching processes, which will also be evaluated by all project partners over a six-month period of practice. Importantly, the above activities will be attended by students - future teachers for whom the project constitutes an opportunity to acquire knowledge and skills (also in real working conditions) from people who have already practised their profession, as well as from domestic and foreign researchers and experts. In addition, it is a good opportunity to understand the learning process and the role of good school, where the teacher should be "an experienced companion in the learning process," (Salcher, 2009, p. 36) viewed by the students as an interesting person, who is strongly involved in activating young people and supporting the development of their talents, engaged in the undertaken activities and willing to learn. We should also not forget about schools included in the project, their teachers and their vast experience.

\section{Today's students (including the unteachables) in literature - an attempt to sketch their profile}

According to Jean M. Twenge (2019), professor of psychology and influential research, the features of the "new generation" ${ }^{2}$ are global and affect various environments, and today's students seriously challenge education. Unfortunately, school is becoming an increasingly less important place for young people, who often pursue their goals outside its premises. Similar opinions can be found among others in

1 Information about the institutions and persons participating in the project, the effects of the teams' work can be found on "The Unteachables" Erasmus+ project website: https:// theunteachableserasmus.blogspot.com.

2 Also described by J. M. Twenge (2019, p. 13) as the Internet Generation - iGen (abbreviation for iGeneration starting with post-millennials born in 1995): "iGen is the first generation that entered adolescence with a smartphone in hand". 
Rick Wartzman's text (2014). Referring to the Intelligence Group analyses, he drew attention to the critical approach of Generation $\mathrm{Z}^{3}$ to spending time in a traditional classroom. It is a generation that primarily values passion, experience and the opportunity to influence the world, even at the expense of formal education (Tapscott, 2010; Wartzman, 2014). At the same time, young learners (the following statements apply mainly to college and university students, but according to the author of this text they can also refer to secondary school students) want safe educational spaces where they can also "shelter" from confrontation with other opposing views. This may result, among others due to the fact that people grown up "in the web" often lack traditional social training and the ability to react in various situations, e.g. when receiving critical comments. "Generation Snowflake" (the term used by columnist Claire Fox) is particularly sensitive to negative assessments, ideas that are in conflict with their beliefs, and they are usually not prepared to take risks, which builds up young people' insecurity.

Further features and expectations of the "new generation", also related to its educational activity, have been presented in the text $\mathrm{t}^{4}$ : "Interests and their participation in the activity of young people. Experiences gained from, among others 'The Unteachables' Erasmus+ project", referring to theoretical analyses and empirical research by such authors quoted below as: Agnieszka Cybal-Michalska, Natalia Hatalska, Mariann Hardey and Marc Prensky. It is worth adding that these features are also becoming part of the national, social debates about good school (and the accompanying reports ${ }^{5}$ ) the project may be coherent with.

Among unteachable young students there may be people who are not interested in learning because of, for example, too high peer pressure to take up studies; who have problems with independent learning (commitment) or adapting to school/ class rules; who do not enjoy learning and do not expect positive results from their activities; or who are afraid of failure (Hashim \& Hussain, 2006; Khondaker, 2007; Szcześniak \& Rondón, 2011).

According to Ken A. Robinson (2015), a specialist in the development of creativity and innovation, many modern students believe they have learning difficulties, also associated with the lack of motivation, and in fact they have problems with

3 According to Maria Czerepaniak-Walczak (2010, p. 56), the scale and pace of change are the basic attributes of modern times: "The subsequent letters of the alphabet: $\mathrm{X}, \mathrm{Y}, \mathrm{Z}$ indicate the dynamics of the change in the specifics of generations."

4 This publication (submitted for printing) is also related to author's (A. Kulpa-Puczyńska) participation in the work of the Youth Pedagogy Panel (including the working group: the Youth between education and the labour market, headed by Professor Magdalena Piorunek) operating at the Committee of Pedagogical Sciences of the Polish Academy of Sciences. Information about the Youth Pedagogy Panel can be found, among others on the website: http://zpm.home.amu. edu.pl/

5 An example is the analysis of the Educational Research Institute, including the report of A. Nowakowska and J. Przewłocka (2015). 
the commonly required way of learning. Don Tapscott (2010) adds that students forgo learning because they often suffer from passive participation and become bored during school hours. They do not have any influence on what, when, where and how they learn. A solution for these students may be a system based on real aptitudes and interests of young people, also creating opportunities to learn at their own pace, interact with other people and use interactive methods, e.g. the flipped classroom method described by K. A. Robinson (2015). Unfortunately, today we do not exploit schoolchildren's potential - according to M. Prensky (2016, p. 4): "We should ask them not to improve the world someday, when they become adults, but now, while they are still in school, and still students." The above-mentioned issues will be the subject of an analysis undertaken in the next text, also referring to one of the goals of "The Unteachables" Erasmus+ project - searching for the best forms and methods to use the potential of 'new' students.

\section{Features of unteachable students in analyses by the Polish project team}

The introduction to this part of the article should start with information that the research (quantitative and/or qualitative) concerning problems raised in the project were conducted, among others in partner schools in countries involved in project activities, and the results of preliminary research and their analyses were presented and discussed also during team meetings in Ljubljana in April and in Warsaw in September 2019. The national research was conducted with the help of the diagnostic poll method, survey technique (online) developed for the purpose of the research, which allowed to present the main problem in a broader context. A tool, prepared also for secondary school students, is the result of the project team's work (with the active participation of school principals, teachers and students) and of pilot studies conducted in the cooperating schools, in selected classes. In turn, in the case of qualitative research, the project partners decided to collect stories of individual students, future teachers and practising teachers, observations of surveyed students, personal narratives of teacher-researchers.

This article focuses on unteachable students' strengths that can constitute an opportunity for learners (e.g. with the support of creative and open teachers ${ }^{6}$, who can pick out the needs, passions of their students and help realise them, which also stood out during the analysis of data obtained from students from native, cooperating schools, as well as the dialogue with project partners from other countries). This also seems relevant in the context of one of the problems raised here, which has already been stressed in the title of this article. We are talking about the potential

6 Also taking into account the fact that an increase in the number of authorities in school relations has been observed. "Over three-quarters of students declare that they have a teacher whom they particularly value, respect or like." $82 \%$ of public secondary school students claimed so, after: M. Bożewicz (2019, pp. 46-47). 
Chart 1. Respondents' answers to the question about the motivation to acquire knowledge and its sources (related to the school environment). Respondents could select more than one answer

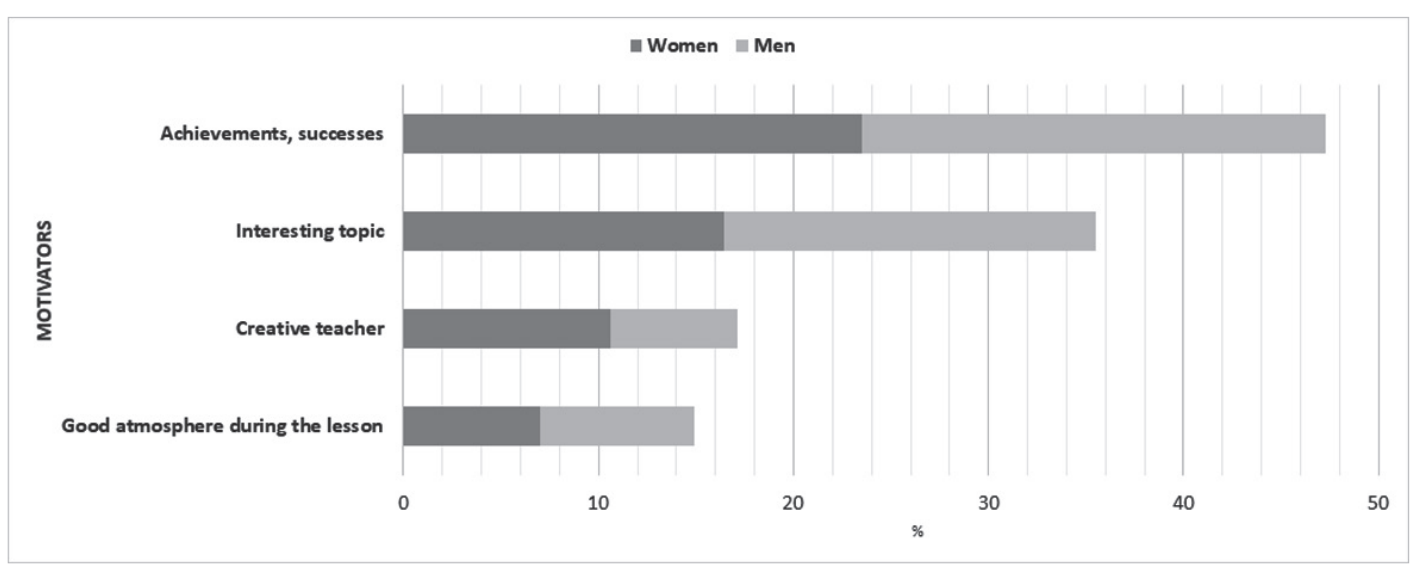

Source: An own study based on the results of research conducted by the Polish team as part of "The Unteachables" Erasmus+ project.

Chart 2. Respondents' answers to the question about obstacles in school learning (concerning the cooperation between student and teacher). Respondents could select more than one answer

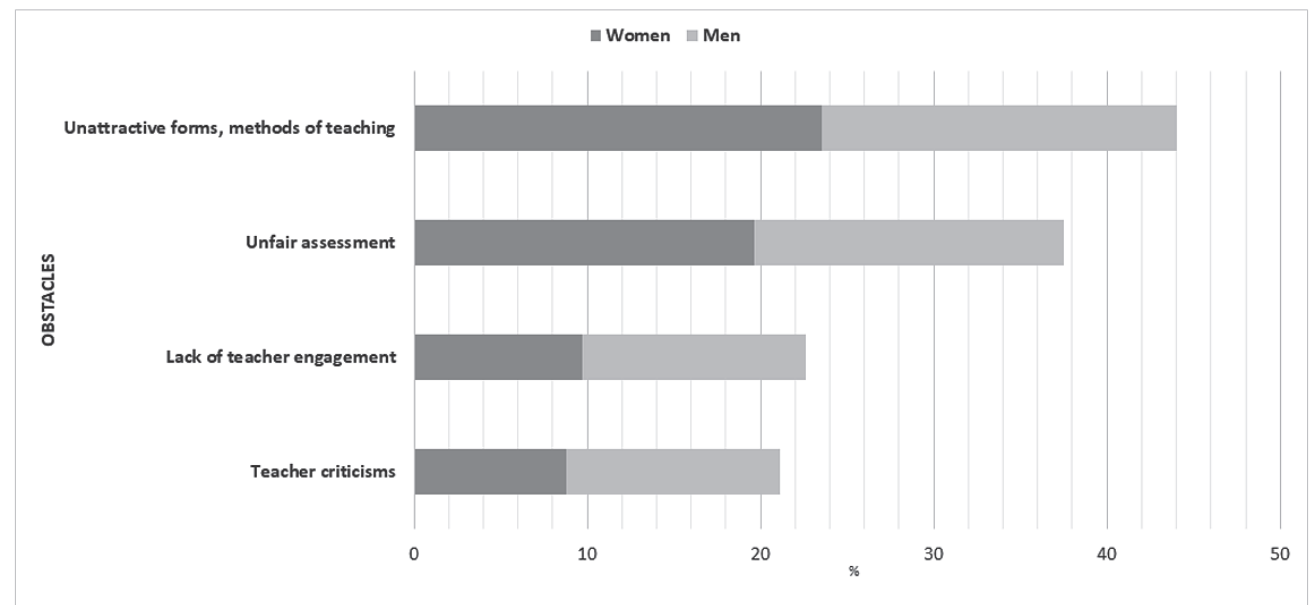

Source: An own study based on the results of research conducted by the Polish team as part of "The Unteachables" Erasmus+ project.

of future teachers who may become also specialists for the 21st century education. What else can be a guideline for young educators - working with "new" students, including probably the "unteachable" ones?

In turn, among the characteristics of the surveyed people ${ }^{7}$, attention was paid, among others to the following interconnected preferences:

7 The group of respondents included 172 men and 169 women. Students between 12-16 years (this age range is important for "The Unteachables" Erasmus+ project) accounted for the total of $83 \%$. 
- Openness to "new" learning places, which is displayed in Chart 3 (characteristic to over one third of respondents) - outside the school classroom, learning in the open air, experiencing the world in the field, during trips. Together with the very welcome and popular learning at home, in an own room (286 students replied so) - supported by, for example, e-learning;

- The need to work on projects the respondents find interesting; taking part in experiments ("definitely yes" was marked by 217 surveyed students, "rather yes" $\left.-90^{8}\right)$. It can also be associated (projects) with the willingness of respondents to learn/self-study in the so-called third places: libraries, reading rooms, bookshops, cultural institutions;

- Having many interests and passions, which the respondents devote a lot of time to, often at the expense of studying individual subjects. Here, it is worth mentioning about almost $74 \%$ of answers suggesting low interest in school activities?. Students realise themselves mainly after school, also spending time on the Internet, e.g. in the world of games.

Chart 3. Respondents' answers to the question about the environment/place where they prefer to learn/study (outside the traditional classroom). Respondents could select more than one answer.

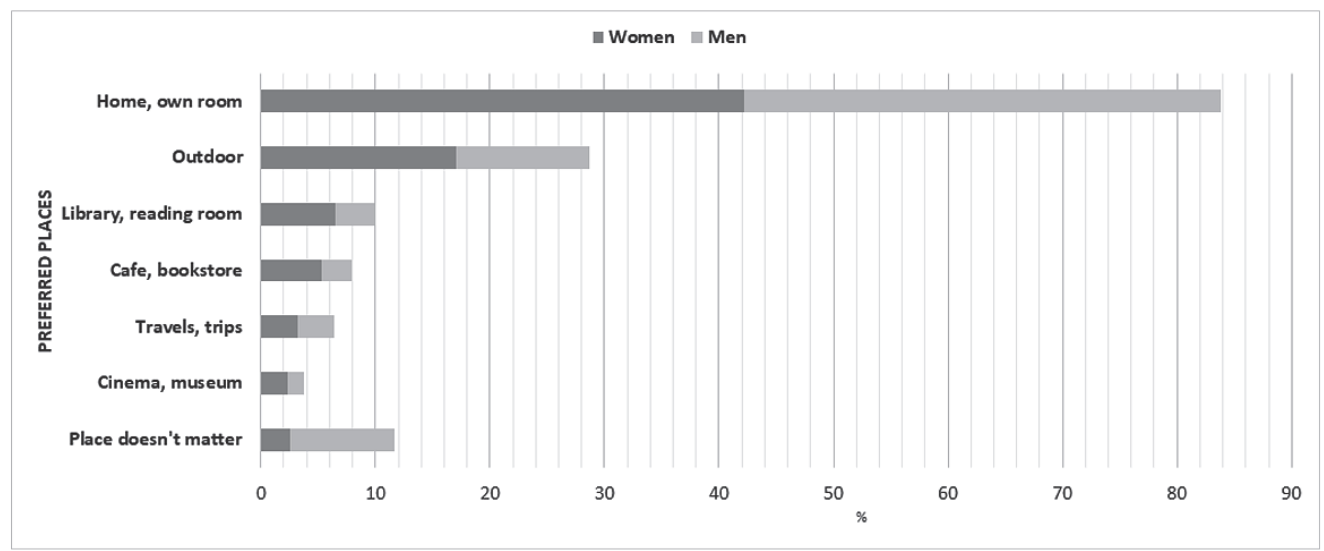

Source: An own study based on the results of research conducted by the Polish team as part of "The Unteachables" Erasmus+ project.

The above data may indicate that the respondents need more flexibility and diversity in relation to standard time and place of learning, organisation of a routine school day. They expect learning opportunities in multiple circumstances,

8 Detailed data can be found on the project website (Results), in the document: Profiling students. Step 1.

9 Detailed data can be found on the project website (Results), in the document: Profiling students. Step 1. 
not just in the classroom, but preferably outside of it. Inspiration here can include, e.g. a student-centred method of teaching art, which activates students through watching, analysing artistic works, but also creating art in various situations, individual practice (Beech, 2014; Hjelde, 2015), as well as other types of projects (e.g. local, team), which take into account the ideas and experiences of young people and include their out-of-school initiatives. An interesting issue provides a boost in students' motivation to acquire knowledge (Chart 1), while uninteresting topics and difficult, extensive material can pose significant obstacles in the learning process. The presented results constitute part of the portrait of modern young learners, which is also outlined in the theoretical part of the study. They emphasize the importance of "safe" learning space (such as an own room).

The above features and the accompanying author's reflections (created on the basis of 341 responses obtained from students) require further evaluation, not least because they concern other cognitively interesting problems, e.g. the organization of today's school spaces, or ways to create an appropriate atmosphere in schools/ classes - which would favour various educational activities, interactions and exchange of knowledge between learners as well as between teachers and students. They are also important due to the fact that the youngest generation (brought up in an environment of digital technologies) highly values flexibility and mobility, also in relation to study and work places (Tapscott, 2010), striving - in the abundance of many classes, passions - for a certain balance between various spheres of their activity (Kulpa-Puczyńska, 2018; Wysocka, 2011). In addition, the features of unteachable young students, highlighted by the Polish project team ${ }^{10}$, do not make a finite list. The problems raised in the project are complex, hence the team members consider the so-far-obtained data as a starting point for further research and evaluation, also in relation to profiles of unteachable learners. They have also been the subject of analyses conducted by researchers and experts from various countries. Nevertheless, "The Unteachables" project has let these problems resound also in the opinions of "new" students.

\section{Conclusions and project plans made with the participation of young teachers}

Summing up the earlier considerations, it is worth adding that the described project is future-oriented and also towards an emerging group of students and teachers. It should also be recalled that from November 2019 new learning strategies and

10 They have been subjected to preliminary analyses (quantitative and qualitative) also in "PROFILING STUDENTS first draft for project discussion and consultancy review," Cardinal Stefan Wyszynski University 2019, available on the project website. The report is based on the responses of 121 respondents and comments of participants of the Polish project team, collected and described by its coordinator - Artur Baranowski, Faculty of Biology and Environmental Sciences at the Cardinal Stefan Wyszynski University. 
tools for students will be tested, based, among others on the use of new technologies ("The Unteachables" Erasmus+ project concludes in August 2020). Digital technologies, their advancement and accessibility, have changed teaching and learning methods, offering e.g. new working methods, programs and platforms adapted to the individual needs of students, transferring education to previously inaccessible places (Price, 2013; Robinson, 2015). In addition, the project activities include: ${ }^{11}$ academic teachers and secondary school teachers who have only started their professional careers, also secondary school students and university students near-future teachers ${ }^{12}$ preparing to cooperate with the new generation of students. At this point, it is required to emphasise once again that the goal of the project is also to help young teachers "transform" the increasingly more unteachable young students into young learnables. Hence the commitment of students and teachers (in their workplace) to participate in various project tasks, including, among others: planning and conducting research; analysing the obtained results, which can also be used to identify, evaluate and present effective "learnables" strategies with relevance to secondary schooling; as well as developing guiding principles for the above-mentioned school experiments. In the case of the last two actions, the above was implemented mainly during a working meeting of all project teams in Warsaw in September 2019, organised by the Mazovian Self-Government Teacher Training Center (MSCDN). This workshop meeting ensured a convenient space for the presentation of diverse views and common positions on teaching and learning, including in the opinion quoted by K. A. Robinson (2015, p. 98) that "the best place to start thinking about how to change education is exactly where you are now." When writing about the significant participation of students in the project - giving them the opportunity to experiment and cooperate - but also about the participation of external stakeholders of the university, the author of the paper also meant the concept of a committed university, described more broadly (including in relation to the Cardinal Stefan Wyszynski University's activities) in the publication The model of cooperation with employers as the support measure for the development of entrepreneurial university potential (Kulpa-Puczyńska, 2015).

11 Information about the members of the Polish project team, cooperating general secondary schools and activities carried out so far can be found on the project website and the websites of the Faculty of Education and Faculty of Biology and Environmental Sciences at the Cardinal Stefan Wyszynski University.

12 The author of the paper encountered the term "near-future teachers", well fit to the described situation, among others during the 1oth National Pedagogical Congress "Pedagogy and education in the face of the crisis of trust, community and autonomy" held on 18-20 September 2019, in the title of the speech by Anna Weissbrot-Koziarska, titled: "Alexa, Siri, Cortana - near-future teachers." 


\section{References}

Beech, D. (2014). Teaching The Unteachable. Art Monthly, 377, 8-10, after: Hjelde K. (2015). Paradox and potential: Fine art employability and enterprise perspectives. Art, Design \& Communication in Higher Education, 14(2), 175-188. DOI: https:// doi.org/10.1386/adch.14.2.175_1.

Bożewicz, M. (2019). Relacje szkolne. In M. Grabowska \& M. Gwiazda (Eds.). CBOS. Opinie i diagnozy nr 43. Młodzież 2018. Warszawa, 46-47.

Czerepaniak-Walczak, M. (2010). Zaskakujące, intrygujące, niezwyczajne obrazy młodzieży. Próba zastosowania koncepcji „Czarnych Łabędzi” w pedagogice młodzieży [Surprising, intriguing, unusual images of the youth. An attempt to apply the concept of "Black Swans" in youth pedagogy]. Przeglad Pedagogiczny, $1,52-64$.

Hashim, F., \& Hussain R. M. R. (2006). Teachers of The Unteachables. Journal on School Educational Technology, 1(4), 22-25. Retrieved from: https://files.eric. ed.gov/fulltext/EJ1064228.pdf

Khondaker, M. R. (2007). NEETs' Challenge to Japan: Causes and Remedies. Japanstudien, 18(1), 221-244. Retrieved from: https://www.tandfonline.com/ doi/abs/10.1080/09386491.2007.11826943

Kulpa-Puczyńska, A. (2015). The model of cooperation with employers as the support measure for the development of entrepreneurial university potential. In E. De la Poza, J. Domènech, J. Lloret, M. Cinta Vincent Vela, \& E. Zuriaga Agusti (Eds.). 1st International Conference on Higher Education Advances, HEAd'15. València: Universitat Politècnica de València (pp. 326-333). Retrieved from: http://ocs.editorial.upv.es/index.php/HEAD/HEAD15/paper/viewFile/435/255.

Kulpa-Puczyńska, A. (2019). Individual Entrepreneurship in the Context of Diversity and Flexibility of Workplaces. In D. Tipurić \& D. Hruška (Eds.). 7th International OFEL Conference on Governance, Management and Entrepreneurship: Embracing Diversity in Organisations. April 5th-6th, 2019, Dubrovnik, Croatia, Governance Research and Development Centre (CIRU). Zagreb, pp. 340-350. Retrieved from: https:/www.econstor.eu/bitstream/10419/196091/1/ofel-2019-p340-350.pdf.

Nowakowska, A., Przewłocka, J. (2015). Szkoła oczami uczniów: relacje z nauczycielami i kolegami oraz przemoc szkolna [School through the students' eyes: relationships with teachers and classmates and school violence]. Warsaw: The Educational Research Institute.

Prensky, M. (2016). Education to Better Their World. The Emerging Alternative for K-12 Education, pp. 1-9. Retrieved from: http://marcprensky.com/wp-content/ uploads/2016/05/+++Prensky-Education_to_Better_Their_World-essay-o1.pdf.

Price, D. (2013). Open: How We'll Work, Live and Learn in the Future. Crux Publishing. 
Robinson, K., \& Aronica, L. (2015). Kreatywne szkoły. Oddolna rewolucja, która zmienia edukacje [The Grassroots Revolution That's Transforming Education]. Kraków: Wydawnictwo Element.

Salcher, A. (2009). Utalentowany uczeń i jego wrogowie. Rzeszów: Wydawnictwo Oświatowe Fosze.

Szcześniak, M., \& Rondón, G. (2011). Pokolenie „ani-ani”: o młodzieży, która się nie uczy, nie pracuje i nie dba o samokształcenie. Psychologia Społeczna, 3(18), 241-251. Retrieved from https://www.researchgate.net/publication/276027016_ Pokolenie_ani-ani_o_mlodziezy_ktora_sie_nie_uczy_nie_pracuje_i_nie_ dba_o_samoksztalcenie.

Tapscott, D. (2009). Grown Up Digital. How the Net Generation is Changing Your World. Introduction. Published by The McGraw-Hill Companies, Inc.

Tapscott, D. (2010). Cyfrowa dorosłość. Jak pokolenie sieci zmienia nasz świat. Warszawa: Wydawnictwa Akademickie i Profesjonalne.

Twenge, J. M. (2019). iGen. Dlaczego dzieciaki dorastajace w sieci sa mniej zbuntowane, bardziej tolerancyjne, mniej szczéśliwe - i zupełnie nieprzygotowane do dorosłości - i co to oznacza dla nas wszystkich [iGen: Why Today's SuperConnected Kids Are Growing Up Less Rebellious, More Tolerant, Less Happyand Completely Unprepared for Adulthood-and What That Means for the Rest of Us]. Sopot: Wydawnictwo Smak Słowa.

Wartzman, R. (2014). Coming Soon to Your Office: Gen Z, „Time”. Retrieved from: https://www.drucker.institute/thedx/coming-soon-to-your-office-gen-z/.

Wysocka, E. (2011). Praca jako czynnik warunkujący jakość życia ludzi młodych - psychospołeczna perspektywa teoretyczna [Work as An Item of Providing Quality of Life for A Young Person - a Theoretical Psycho-social Perspective]. Forum Pedagogiczne", 1, 12-44.

\section{CECHY „NOWYCH” UCZNIÓW I POTENCJAŁ PRZYSZŁYCH NAUCZYCIELI. PIERWSZE WYNIKI MIĘDZYNARODOWEGO PROJEKTU „THE UNTEACHABLES”}

Streszczenie: Znaczący staje się dzisiaj problem uczniów z trudnościami w funkcjonowaniu w środowisku szkolnym, które często nie odpowiada na unikalne i złożone potrzeby młodych osób uczących się, dotyczące np. nowoczesnych sposobów wymiany doświadczeń oraz wiedzy czy możliwości aktywnego uczestnictwa we wspólnocie uczących się i sieci wsparcia. Oznacza to m.in. konieczność tworzenia nowych zasobów edukacyjnych (powstałych także na bazie współpracy środowiska akademickiego z nauczycielami szkół średnich, kooperacji ekspertów i praktyków z różnych krajów) dla przyszłych nauczycieli, którzy będą musieli stawić czoła np. problemowi „wypalonych” uczniów. Głównym celem tekstu jest podzielenie się pierwszymi wynikami badań oraz refleksjami związanymi 
z realizacją na Wydziale Nauk Pedagogicznych oraz Wydziale Biologii i Nauk o Środowisku Uniwersytetu Kardynała Stefana Wyszyńskiego w Warszawie (we współpracy z partnerami z Danii - koordynator projektu, Islandii, Hiszpanii Słowenii i Włoch) projektu Erasmus+ „The Unteachables”.

Słowa kluczowe: „nowi” uczniowie; przyszli nauczyciele; szkoły średnie; uniwersytety; współpraca; projekt Erasmus+.

Aleksandra Kulpa-Puczyńska - Doctor of Humanities with specialisation in pedagogy; Assistant Professor at the Faculty of Education at the Cardinal Stefan Wyszynski University in Warsaw. She focuses on issues concerning preparation to professional work, collaboration of schools with business entities and entrepreneurial activity of young people in the dynamic professional reality. Her academic contribution consists of over 50 publications, including articles, mainly in the field of labour pedagogy and andragogy. She is a member of the Youth Pedagogy Panel operating at the Committee of Pedagogical Science of the Polish Academy of Science (PAN). She can be contacted at: a.kulpa-puczynska@uksw.edu.pl 

MAŁGORZATA BANASIAK

Wydział Filozofii i Nauk Społecznych

Forum Pedagogiczne

Uniwersytet Mikołaja Kopernika

$9(2019) 2$, cz. 2

Wpłynęło: 05.10.2019

Toruń

ORCID ID: https://orcid.org/oooo-ooo1-9732-6178

AGATA WOŁOWSKA

Wydział Filozofii i Nauk Społecznych

Uniwersytet Mikołaja Kopernika

Toruń

ORCID ID: http://orcid.org/oooo-0oo3-1864-3920

\title{
DEMENTAGOGY: NON-PHARMACOLOGICAL FORMS OF SUPPORT FOR PEOPLE WITH DEMENTIA
}

\begin{abstract}
The article presents quite a new part of pedagogical sciences - dementagogy. The exploratory goal of the article is to indicate new areas of research within special pedagogy that refer to dementagogy and new challenges that aging societies pose to educators. Facilitation strategies directed at people with dementia is one of the challenges but also a great option for non- pharmacological forms of support. The main objective of dementagogy is accompanying a person with dementia in the process of painful parting with oneself and supporting this person in the difficult process of the disease. In the article you will find selected methods of non-pharmacological support for patients with dementia such as Cognitive therapy - RehaCom, Reminiscence therapy, Music therapy, Relaxation, Validation therapy, Occupational and movement therapy, Environmental therapy. Art therapy, Self Maintenance Therapy.
\end{abstract}

Keywords: dementagogy; special geragogy/gerogogy; the elderly; Alzheimer; therapy; non-pharmacological support methods.

\section{Introduction}

Aging societies is an issue of concern for many countries around the world. Due to a longer lifespan we face more age-related conditions. Dementia is an ever-growing problem of patients visiting their family doctors but it also frequents residents of nursing homes. An important but underestimated part of special pedagogy 
is gerogogy, and more precisely its new subdiscipline, pedagogy of people with dementia.

"In view of the biologically conditioned degenerative processes occurring in aging and elderly people, in the face of increasing loneliness and isolation, in the face of a significant dependence on the external world and an unknown environment, there is the same therapeutic and pedagogical responsibility which is undertaken in order to stimulate the development of children and youth with disabilities or at risk of disability." (Bachmann, 1990, p. 89)

The exploratory goal of the article is to indicate new areas of research within special pedagogy that refers to dementagogy. The practical aim is to describe non-pharmacological support methods that can be used in therapeutic work with patients with dementia. The rationale for this paper is to address the missing gap in dementia therapy.

The research method used in this paper is the analysis of professional literature (books, articles, research results, interviews with therapists) and internet resources. The article provides the review of non-pharmacological support methods used in various countries when working with people with dementia and the research indicating the effectiveness of the impact of the methods listed on particular spheres of life of the target group.

\section{Dementagogy}

The traditional geragogy has been focused so far on a normally aging person. The beginning of our century clearly draws our attention to the social issues of the elderly, which is reflected in the creation of special geragogy, whose subdiscipline is the pedagogy of people with dementia - dementagogy (Zych, 2014).

This relatively new area of science under the name of geragogy was created in relation to the fact that the great majority of methods supporting people with dementia is strictly connected with special pedagogy. This term understood as "education of aging and old people" was also used in 1952 by F. Kehrer (Szarota, 2014). Then, Steurenthaler, a German educator and psychologist, suggested using the term dementagogy. According to Steurenthaler (2012), the main aim of dementagogy is to accompany a person with dementia in the process of painful parting with oneself and supporting this person in the difficult process of the disease. The support is understood as providing care and various forms of support both to the patient and their immediate family. The notion of dementagogy appeared also during the European Year of Brain (2014), where the vision of promoting a dementia-friendly society was presented (Zych, 2014). Thus, the introduction of the notion of dementagogy, that considerably increases the field of spatial pedagogy, seems to be sensible due to the growing number of patients with different kinds of dementia, and consequently, the necessity of both therapeutic and research activities in this area. 


\section{Dementia}

Over the years, several definitions of dementia (in Latin. dementia) have been formulated. According to the International Statistical Classification of Diseases and Related Health Problems ICD-10, dementia is a syndrome caused by brain disease, usually of chronic or progressive nature, in which the following cortical functions (cognitive functions) are impaired: memory, thinking, orientation, understanding, numeracy, learning capabilities, language and assessment. ${ }^{13}$ The experts of the World Health Organisation (WHO) state that the basic diagnostics criteria of dementia include disorders of memory and other cognitive functions, i.e. thinking, assessment, planning, organising and general information processing disorders. Although "spatial awareness" is preserved, there may occur the decrease of emotional control over motivation or a change in social behaviour demonstrated as affective lability, i.e. emotional instability, irritability and mood disorders, apathy, euphoria or dysphoria, as well as primitivisation of social behaviour. The described symptoms are usually present for the period of at least 6 months. According to DSM-IV classification, dementia is a syndrome of disorders in cognitive processes, comprised of, apart from memory disorders, deficits of at least two of the following functions: speech (aphasia), purposeful complex movement actions (apraxia), the ability to recognise and identify objects (agnosia) and disorders of planning, initiating, controlling and correcting the course of complex behaviour (executive functions disorders). Cognitive deficits are so deep that they impair professional activity, social functioning and the performance of everyday activities (DSM-IV, 2012).

The dementia process starts with the mild occurrence of difficulties in the areas mentioned above, followed by a gradual deterioration of cognitive functions (Kaplan, Sadock \& Sadock, 2001, p. 43). Various forms of dementia include frontotemporal dementia, dementia in Parkinson disease, dementia with Lewy bodies and dementia in Alzheimer's disease.

The literature describes different forms of support provided to patients with dementia. The researchers suggest that pharmacological treatment is not sufficient to prolong independent functioning of patients. Alternative and supplementary support approaches may or even should be used (Borzym, 2010). They emphasise that some behaviour that mimics care, can harm the patient. Here, we should mention the incorect methods care provision, namely, overprotection and negligence; these two forms may lead to the situation when the patients will function below their capabilities.

According to Borzym (2010), the behaviour of the person with dementia depends on the progressive changes within the brain. In connection with the fact that the

13 ICD-10 Classification of Mental and Behavioural Disorders. Institute of Psychiatry and Neurology.

Vesalius. Kraków-Warszawa (1998). 
changes lead to worsening memory and other cognitive processes, they cause at the same time growing difficulties in understanding the reality surrounding the patient. Therefore, it is necessary to implement various kinds of activities activating the person with dementia, the aim of which is to stimulate existing cognitive abilities. They are to help in maintaining practical skills, improve well-being and alleviate behavioural disorders. The choice of activities shall be individual and shall depend on the stage of dementia as the best results can be achieved by using exercises based on the skills that are relatively well preserved and, at the same time, requiring the patient's engagement (Długosz-Mazur, Bojar \& Gustaw, 2013).

Dementagogy is a very important part of special pedagogy and sets new roles in the work of educators. Pedagogy is not confined to educating children but also grown-up people, including those with dementia. The non-pharmacologicalal interventions is not a task for physicians who prefer drug treatments, but for educators, social workers and psychologists.

\section{Selected methods of supporting patients with dementia}

Among various kinds of support possible to implement in dementagogy, the following ones can be distinguished: RehaCom cognitive therapy, reminiscence therapy, validation therapy, music therapy, movement therapy, occupational therapy, environmental therapy and art therapy. Self-Maintenance Therapy is a very interesting complex therapy for dementia patients. All those forms of therapeutic influence are the elements of dementagogy and they refer to professional activities and accompanying the person with dementia or the person suffering from Alzheimer's disease. Whichever therapy method is chosen, the daily routine is very important in the procedures with a dementia patient. Any deviations from the routine should be avoided as they can increase the patient's anxiety (Kłoszewska, 2012).

\section{Cognitive therapy - RehaCom}

Cognitive therapy - RehaCom is a kind of computer-assisted rehabilitation of cognitive functions. It is an example of a non-pharmacologicalal form of therapy, whose aim is to improve patients' performance with all kinds of brain cognitive functions disorders. This aim is achieved by designing special, patient-friendly re-educational programmes. RehaCom has a module structure (it consists of over 20 modules) and can be configured to meet the patients' capabilities and adjusted to their individual needs, which, in turn, enables improvement of their brain functions. With the use of this method, children and adults can be diagnosed and their cognitive abilities such as verbal and non-verbal memory, attention, concentration, logical thinking, problem solution abilities, memory and face recognition, visual and movement coordination, planning functions and cognitive functions after stroke or cerebral hemorrhage can be trained (HASOMED, 2018). RehaCom can 
be used particularly for children with ADD (attention-deficit disorder), ADHD (attention-deficit/hyperactivity disorder) and learning difficulties. This form of therapy is also recommended and very effective in case of children and adults with cognitive functions disorders caused by focal or general brain damage. The main advantage of the RehaCom therapy is the fact that the system has the function of autoadaptation to the patients' abilities, and it ensures continuity and effectiveness of the training as well as positive motivation of the patients.

\section{Reminiscence therapy}

Another important type of nondrug therapy is reminiscence therapy. It consists in recalling memories with the use of stimulating materials. The prompts used for the therapy can include photographs, keepsakes, smells, music or visits to familiar places. In case of difficulties in remembering current matters, reminiscing gives the patients the sense that they still remember well a lot of things and the disease did not affect each aspect of their memory. Recalling positive memories also causes the improvement of well-being and positive attitude to life. Strictly speaking, the reminiscence therapy influences the psyche of the patient by facilitating a recall of the most important personal experiences, consisting in a stimulation of brain areas connected with so called "memory anchors", i.e. memorised and reiterated memories, which alleviates behaviour disorders and can improve memory and space orientation. Therapists who use this method claim that patients can reach back to their past experiences when they could face difficult situations. Memories of this type can improve self-esteem, or stimulate self-expression in public to sustain social bonds (Pietraszek-Kusik, 2015).

Other reminiscence therapy forms worth mentioning, used with patients living permanently in senior homes, are simulated contacts with the family (watching films, viewing photos) and a therapy with the use of dolls and soft toys. The observation conclusions indicate the improvement in the area of anxiety decrease and sleep time among the examined persons. For this method to be successful good relationship of the patient with the family, good sight and hearing and mild stage of dementia are required. (Zetteler, 2008).

\section{Music therapy}

Music therapy is a frequently discussed example of a therapy using reminiscence as well as elements of relaxation and movement therapies. Music therapists, in their clinical practice, use music as a means which effectively affects the treatment of various diseases and disorders as well as fosters the development of the patient's resources. Music therapists can use words, words with music or only music, which reflects multitasking nature of the music therapy (Rusowicz, 2017). How music stimulation influences perception in patients with Alzheimer's dementia 
was verified in the United States. Ten songs were selected for each patient taking into consideration previous preferences of the patient and the suggestions of the family. The patients participated in 3 to 7 sessions daily. It was observed that music auto-stimulation may bring benefits to the patients by improving their perception and engagement in therapeutic activities, which may lead to raising their reality awareness/orientation (Lancioni et al., 2013).

The other positive effects of music therapy was a result of „Singing for the Brain" Project of the Alzheimer Association for people with dementia and their caregivers. The therapy and the research were based on singing together. On the basis of the interviews with 20 participants and their caregivers it was stated that it helped in the improvement of relationship with other people, in the memory and mood improvement, better acceptance of the diagnosis and a stronger social integration. The above qualitative research showed how important the singing together was for the project participants (Osman, Tischler \& Schneider, 2016). Very interesting research on the effectiveness of music therapy in the treatment of Alzheimer's patients was conducted in Japan. The hypothesis was made that the music therapy can be an alternative substitute treatment for an unfavorable hormonal therapy because stimulation by music releases various biochemical substances and is strictly connected with steroid hormones, which, in turn, affect emotions and human behaviour (Fukui, Arai \& Toyoshima, 2012). The result of this research confirmed beneficial effect of music therapy on patients with dementia. It should be emphasised that this type of therapy may be used successfully by professional geragogists and therapists, both as a factor supporting other forms of therapy and as one of the basic elements of therapeutic procedures.

As research shows, music therapy modifies the components of the disease through sensory, cognitive, affective and behavioural effects. Receptive music therapy encourages cognitive stimulation, allowing patients to recall autobiographical memories and images (Guétin et al., 2009).

\section{Relaxation}

Beneficial influence of relaxation techniques used for the purposes of removing psychophysical tensions such as muscle relaxation and vegetative functions regulation cannot be ignored. The observations confirm that massage and touch relax the patients. The Japanese research shows significant effects of relaxation on people with dementia. The results suggest that progressive muscle relaxation improves the behavioural and psychological symptoms of dementia and activities of daily living lower the anxiety, apathy and irritability, in group home residents with dementia, but it does not affect their immune function (Ikemata \& Momose, 2017).

Deep breathing seems simple enough but taking time to practise it will help reduce tension, shortness of breath and anxiety. Yoga not only focuses on the body, helping strengthen muscles through a series of stretches and poses, but it 
also concentrates on deep breathing techniques, which is a fantastic way to relieve stress and tension. Visualisation, being similar to meditation, allows the patients to focus on a place that makes them feel relaxed, where they can de-stress and release any tension or anxiety they may be feeling. Touch can be an immensely powerful therapy - just think how much comfort we get from hugging each other. Therefore, massage can also be a useful therapy for someone with dementia (Fox, 2015).

Research shows that symptoms such as memory loss, lack of orientation, depression, addiction, anxiety, combativeness and anger, and sleeping disturbances can be contained or actually decreased through a course in a relaxation techniques (Verna, 2002).

\section{Validation therapy}

Working with patients using the validation therapy is based on the emotional aspect of communication. Its aim is to prompt proper social behaviour, decrease anxiety and fear level and the improve the patient's comfort. Naomi Feil, as a developer of the validation therapy distinguished four disorientation stages in patients with dementia as well as verbal and non-verbal interaction used at each of these stages. In the disorientation stages I and II, verbal techniques of communication with the patients are used. They consist in attentive listening to the patients and informing them which of their expressions make sense and are meaningful as well as learning the feelings of the patients, acknowledging them and ensuring the patients of their significance. Stages III and IV involve non-verbal techniques such as hugging, stroking or using properly selected elements of music therapy.

Sławiński (2017) illustrated the validation method in the following way: "Let us imagine that we are going slowly along the bank of a river. The river current carries a boat with our disoriented patient. We, using all means, try to convince him to anchor by the side where our reality is awaiting him: safe and firm ground under our feet, the house, warm bed, food. We try to show him all those "miracles" and convince him to return to the reality, to real life. The picture story goes on: our patient is not reacting to our calls, is not listening to what we are saying, He is not looking at us at all. He finds himself in the fog of oblivion. The river current carries him further, we both go ahead but still separately - along two parallel lines."

In order to meet him, we have no choice but get into the boat were the patient is. Only then do we have a chance to contact him, understand, help and accompany him. Validation assumes that we match our emotional levels.

The advantage of the validation method is the fact that it allows for consolation of the patients' emotions and improvement of their mood even when they seem to be functioning without any contact. 


\section{Occupational and physical therapy}

The aim of the occupational and physical therapy is to consolidate the skills still possessed by the patients, recreate those that have been lost lately and improve their general fitness. The occupational therapy consists in doing things the patient enjoyed in the past, i.e., drawing, painting, knitting, plant keeping, gardening and housework, etc. This method can be applied during group classes, however the best results can be achieved by engaging the patients in their house chores. The literature emphasises a great significance of this form of therapy as it satisfies psychological and social needs of the patient, maintains preserved skills, counteracts behaviour disorders and gives the patients the sense of "being needed". Worth mentioning is also the fact that this method is very easy to apply.

The activities conducted within the occupational therapy could be divided into individual:

- work simulation (sorting, arranging, vegetable and fruit peeling),

- manual (with the use of aids, making puzzles, shape matching),

- movement (walking, physical exercises),

- and group:

- movement (team games, dance),

- other activities (watching films, photographs together, reading aloud) (Ponichtera-Kasprzykowska, Pekala \& Sobów, 2013).

Hooghiemster and Eggermont (2012) published results of their research on patients with mild, recently diagnosed dementia, who had been doing a complex set of physical exercises (aerobic level exercises, improving agility and relaxation exercises) regularly, 3 times a week, for a period of 3 months. They noted a significant improvement in independent functioning (ADL Katz Index and Lawton Scale ${ }^{14}$ ). They also confirmed improvement inthe quality of life $(\mathrm{QoL})$ psychomotor speed. Also, Liberati and Raffone (2012) positively evaluated the effect of individually customized cognitive processes training on the patients' independence.

\section{Environmental therapy}

When people with dementia move to a nursing home, they are often unable to locate places, feel a sense of belonging, and orient themselves within the new unfamiliar setting. This results in a loss of autonomy, and also affects the quality of provided care. The transfer from one's home to a care facility can be stressful (Van Hoof, 2007). That is why it is recommended to let people with dementia stay in their environment for as long as they can.

14 Katz Index of Independence in Activities of Daily Living allows for the assessment of the patients' ability to function independently. The Lawton Scale assesses the person's ability to perform more complex activities of daily living. 
There are many different aspects of environmental therapy that can be provided at the patients' own home or at a nursing home.

The environmental therapy consists in creating a friendly and safe environment for the patient. The activities which we treat as environmental enhancements can be divided into two groups: 1) natural (e.g. access to a garden, park, forest), 2) simulated (looking at photographs of nature, of the patient's house, listening to natural sounds, aromatherapy (Ponichtera-Kasprzykowska et al., 2013). It should be remembered that in order to design safe environment for the patient the following guidelines shall be observed: 1) the layout of the whole building and rooms must be simple and clear, 2) the rooms must be clearly marked (e.g. bathroom), 3) they must be designed for the patients with mobility problems (e.g. rails).

The main argument in environmental therapy is that exposure to certain environmental conditions, such as natural and aesthetic amenities, can alleviate stress and promote physical and emotional well-being (Kaplan \& Kaplan, 1989; Hartig, Mang, \& Evans, 1991).

\section{Art therapy}

Art therapy, i.e. therapy through art, is an important element of therapy in various diseases and disorders. Positive effects of creative or artistic approaches to dementia care, support previous research on the use of such approaches in dementia care services (Rylatt, 2012). Further research on the immediate and longer-term outcomes and benefits of creative therapy for people with dementia is recommended to support the routine availability of such a therapy in dementia care (Mottram, 2003). It was also appreciated in case of patients with dementia, therefore, each nursing institution or rehabilitation centre provides artistic workshops where its patients can develop their creativity. The art therapy has a long history. It was used already at the end of 19th century by two French psychiatrists - A. A. Tardieu and M. Simon, but the notion itself - "art therapy" - was first used first by an English teacher Adrian Hill in 1942. It was Sigmund Freud (1972) who postulated a significant role of artistic creativity in the research of unconsciousness. In Poland, in the beginning of $2 \mathrm{O}^{\text {th }}$ century this method was analysed by a distinguished educator and ethicist - Stefan Szuman, and later by an oncologist from Kraków, J. Aleksandrowicz, who introduced this therapy to hospitals as a supplement for traditional treatment methods. It is very important for the patients with dementia to express their emotions through art of various forms (painting, drawing, cutting, sculpturing, etc.) as, while they are gradually losing contact with reality, art allows them to express their feelings, desires or their present mood. This is possible because creative activities sustain mobility, dexterity as well as spatial and constructive praxis. They also stimulate creative thinking. Moreover, because the art therapy is performed most frequently in groups, it helps in maintaining social contacts. 
Art therapy is not only visual or technical arts. It includes also choreography, i.e. dance therapy and movement therapy which, in general, enables integration of emotions and spirit with the body, releases from stress and allows the abandonment of old movement patterns and acquisition of new ones. Fairy-tale therapy (therapeutic fairy tales) and film therapy (Uler, 2019) are slightly different forms of art therapy, other than music therapy described above.

People who have dementia have problems with communication, cognition and memory, so engagement in art therapy allows for a different formand mode of communication. It allows patients to express their feelings. It activates part of their brain that they may not always activate such as creativity, visual-spatial, hand-eye coordination (Wanko, 2019).

Generally, the greatest advantage of art therapy is the fact that it is accessible for everyone regardless of their age - it can be used by children, adults and senior patients, it is cheap and easy to apply (Sobów, 2007).

\section{Self-Maintenance Therapy}

Self-Maintenance Therapy is an example of a complex non-pharmacological programme for people with dementia. It is a programme implemented by Dr Barbara Romeo, a German therapist of Polish origin. Its theoretical foundation is the concept of Self Maintenance Therapy, which values the optimal use of preserved skills by the patients through their participation in satisfactory everyday activities (Romeo and Eder, 1992). The main idea is to support the patient's sense of identity, through appropriate forms of communication (e.g. showing understanding to the patient without criticism and correction) and avoid failures. The concept of Self Maintenance Therapy comprises three areas: 1) medical treatment, including anti-dementia treatment, 2) rehabilitation programme for patients, 3) psycho-educational programme for caregivers. Self-Maintenance Therapy has an integrative character. It adapts methods of multiple concepts for its aims, such as art therapy or behavioural therapy, and, at the same time, it avoids using deficit-oriented training methods.

\section{Conclusion}

Dementagogy in the modern world is more and more important part of geragogy and special pedagogy, not only because societies are growing older but also because pharmacology should not be the only way of support. This article presents the most important non-pharmacological methods of supporting people with dementia. These methods improve life quality and preserve both physical and mental state. Particularly, it concerns memory training conducted in a friendly environment, properly selected occupational therapy, physical exercises, or elements of music therapy (Długosz-Mazur, Bojar, \& Gustaw, 2013). 
Research proves effectiveness of non-pharmacological interventions with dementia patients. It is recommended by therapeutic guidebooks as first choice procedures for the majority of patients, but the results ofthe research on physicians' practice and clinician's everyday experience shows that it is used relatively rarely (Vasse, 2012).

It seems that there are several reasons for this state of things. The majority of decision makers expect a prompt and effective treatment results, and non-pharmacological methods that require more time, regularity and coordinated actions, seem to be ineffective. Undoubtedly, the additional problem is also the lack of knowledge among health care workers, lack of information and family educators who could present the complex non-pharmacological offer and direct the family. And here the door opens for dementagogy and educators specialising in non-pharmacological methods of support provided for people with dementia and their families.

\section{References}

Bachman, W. (1990). Geragogika jako kompleks zadań pedagogiki specjalnej. Edukacja, 1.

Borzym, A. (2010). Oddziaływania niefarmakologiczne w otępieniu. In T. Parnowski (Ed.). Choroba Alzheimera (pp. 49-51). Warszawa: Wydawnictwo Lekarskie PZWL.

DSM IV (2012). Kryteria diagnostyczne według DSM-IV-TR. Wrocław: Urban \& Partner.

Długosz-Mazur, E., Bojar, I., \& Gustaw, K. (2013). Niefarmakologiczne metody postępowania u chorych z otępieniem. Medycyna Ogólna i Nauki o Zdrowiu, $19(4), 458-462$.

Fox, H. (2015). What relaxation techniques and therapies are good for dementia care? Live better with dementia. Retrieved from: https://dementia.livebetterwith.com/blogs/advice/what-relaxation-techniques-and-therapies-are-good-for-dementia-care (2019.10.24).

Freud, S. (1972). The psychopathology of everyday life of Sigmund Freud. New York: W. W. Norton.

Fukui, H., Arai, A., \& Toyoshima, K. (2012). Efficacy of Music Therapy in Treatment for the Patients with Alzheimer's Disease. International Journal of Alzheimer's Disease, 10.

Guétin, S., Portet, F., Picot, M.C., Pommié, C., Messaoudi, M., Djabelkir, L., Olsen, A.L., Cano, M.M., Lecourt, E., \& Touchon, J. (2009). Effect of Music Therapy on Anxiety and Depression in Patients with Alzheimer's Type Dementia: Randomised, Controlled Study. Dement Geriatr Cogn Disord, 28, 36-46. DOI: 10.1159/000229024

Hartig, T., Mang, M., \& Evans, G. W. (1991). Restorative effects of natural environment experiences. Environment and behavior, 23 (1), 3-26. 
Hasomed (2012). Komputerowo wspomagana rehabilitacja chorych z zaburzeniami funkcji poznawczych. Retrieved from: Rehacom, https://www.biomed.org.pl/ materialy/_upload/KATOLOGIiFOLDERY/Katalog_RehaCom_2012_web_m. pdf (2019.04.09).

Hooghiemstra, A., \& Eggermont, L. (2012). Study protocol: Exercise and cognition in sedentary adults with early-onset dementia. BMC Neurol, 16, 12-75.

Ikemata, Sh., Momose, Y. (2017). Effects of a progressive muscle relaxation intervention on dementia symptoms, activities of daily living, and immune function in group home residents with dementia in Japan. Jpn J Nurs Sci, 14(2), 135-145. Retrieved from: https://www.ncbi.nlm.nih.gov/pmc/articles/PMC5396310/ (2019.10.15)

Kaplan, R., \& Kaplan, S. (1989). The experience of nature: A psychological perspective. CUP Archive.

Kaplan, H., Sadock B., \& Sadock, V. (2001). Psychiatria kliniczna. Wrocław: Wydawnictwo Medyczne Urban \& Partner.

Kłoszewska, I. (2012). Niefarmakologiczne postępowanie w otępieniu. In: Diagnostyka i leczenie otępień. Rekomendacje zespołu ekspertów Polskiego Towarzystwa Alzheimerowskiego. Medisfera, pp. 106-108.

Lancioni, G., O’Reilly, M., Singh, N., Sigafoos, J., Grumo, G., Pinto, K., Stasolla, F., Signorino, M., \& Groeneweg, J. (2013). Assessing the impact and social perception of self-regulated music stimulation with patients with Alzheimer's disease. Research in Developmental Disabilities, 34, 139-146.

Liberati, G., \& Raffone, A. (2012). Cognitive reserve and its implication for rehabilitation and Alzheimer's disease. Cogn Process, 1 (1), 1-12.

Mottram, P. (2003). Art Therapy with Clients Who have Dementia. Art Therapy Service, Manchester Mental Health and Social Care Trust, 2(2), 272-277. DOI: https://doi.org/10.1177/1471301203002002010.

Osman, S., Tischler, V., \& Schneider, J. (2016). 'Singing for the Brain': A qualitative study exploring the health and well-being benefits of singing for people with dementia and their carers. Dementia, 15(6), 1326-1339.

Pietraszek-Kusik, H. Demencja. metody oddziaływań pozafarmakologicznych. Retrieved from: http://www.przeglad.amp.edu.pl/uploads/2015/1/28_1_42_2015. pdf (10.04.2019).

Ponichtera-Kasprzykowska, M., Pękala, K., \& Sobów, T. (2013). Niefarmakologiczne strategie postępowania w zaburzeniach zachowania towarzyszących otępieniu. Aktualności Neurolologiczne, 13(4), 304.

Relaxation Techniques for People with Dementia. Retrieved from: https://www. active-minds.org/news/relaxation-techniques-for-people-with-dementia/ (2019.10.24).

Romeo, B., \& Eder, G. (1992). Selbst-Erhaltungs-Terapie (SET): Konzept einer neuropsychologischen Therapiebei Alzheimer-Kranken. Gerontopsychologie und Psychiatrie, 4, 267-282. 
Rusowicz, J. (2017). Muzykoterapia w chorobie Alzheimera. Polskie Pismo Muzykoterapeutyczne, 4, 32-33.

Romero B. SET Institute (2019). Retrieved from: http://www.set-institut.de/Strona_ polska/body_strona_polska.html (10.04.2019).

Rylatt, P. (2012). The benefits of creative therapy for people with dementia. Nursing Standard, 26(33), 42-47.

Sławiński, L. (2017). Terapia walidacyjna czy łączenie z rzeczywistością. Retrieved from: https://prezi.com/w3do1wphvk-3/terapia-walidacyjna-czy-aczenie-z-rzeczywistoscia/ (10.04.2019).

Sobów, T. (2007). Zasady postępowania terapeutycznego w zespołach otępiennych. Przegląd Neurologiczny, 3.

Steurenthaler, J. (2012). Dementagogik: Dementiell erkrankten Menschen neu und ganzheitlich begegnen, Springer VS College, 6.

Szarota, Z. (2014). Edukacja dorosłych w Polsce i na świecie. Edukacja Ustawiczna Dorostych, 1(84), 13.

Uler, M. Arteterapia-na czym polega lecznicza moc sztuki? Retrieved from: https:// www.poradnikzdrowie.pl/psychologia/zdrowie-psychiczne/arteterapia-na-czym-polega-lecznicza-moc-sztuki-aa-UF78-1hoE-iYKP.html (2019.05.15).

Van Hoof, J., \& Kort, H. S. (2009). Supportive living environments: a first concept of a dwelling designed for older adults with dementia. Dementia, 8(2), 293-316.

Vasse, E., Vermooij-Dassen, M., Cantegreil, I. \& al. (2012). Guidelines for psychosocial interventions in dementia care: a European survey and comparison. Int. J. Geriatr. Psychiatry, 27, 40-48.

Verna, S. M. (2002). Effectiveness of a relaxation technique to decrease the memory and behavior problems of Alzheimer 's patients. Walden University ScholarWorks. Retrieved from: https://pdfs.semanticscholar.org/f6db/d718aoa co9d2fba689cdd35fo2c8bfd94737.pdf (2019.10.24).

Wanko, L. (2019). Art therapy helps dementia patients communicate and connect. Retrieved from: https://www.njtvonline.org/news/video/art-therapy-helps-dementia-patients-communicate-and-connect/ (2019.10.15).

WHO. Retrieved from: https://www.who.int/mental_health/neurology/dementia/ en/ (27.02.2019).

Zetteler, J. (2008). Effectiveness of simulated presence therapy for individuals with dementia: a systematic review and meta-analysis. Aging Ment. Health, 12, $779-785$.

Zych, A. (2014). Pedagogika osób z otępieniem jako nowy obszar geragogiki specjalnej. Labor et Educatio, 2, 271-283. 


\section{DEMENTAGOGIKA - NIEFARMAKOLOGICZNE FORMY POMOCY OSOBOM Z OTĘPIENIEM}

Streszczenie: Artykuł przedstawia stosunkowo nowy dział pedagogiki - dementagogikę. Celem poznawczym artykułu jest wskazanie nowych obszarów badań w zakresie pedagogiki specjalnej, odnoszących się do dementagogiki. Starzenie się społeczeństw stawia nowe wyzwanie przed naukowcami, także z zakresu pedagogiki. Pomoc osobom z demencją należy do wyjątkowych wyzwań, a także jest ogromną szansą na znalezienie niefarmakologicznych sposobów pomocy. Głównym celem dementagogiki jest towarzyszenie osobie $\mathrm{z}$ demencją $\mathrm{w}$ procesie bolesnego rozstania ze sobą i wspieranie tej osoby $\mathrm{w}$ trudnym procesie choroby. W artykule znajdują się wybrane niefarmakologiczne metody wspierania pacjentów $\mathrm{z}$ otępieniem, takie jak terapia poznawcza, rehabilitacja, terapia reminiscencyjna, muzykoterapia, relaksacja, terapia walidacyjna, terapia zajęciowa i ruchowa, terapia środowiskowa.

Słowa kluczowe: dementagogika; geragogika specjalna; otępienie; pomoc osobom starszym; Alzheimer; terapia; niefarmakologiczne metody wsparcia.

Małgorzata Banasiak - doktor pedagogiki, pracownik socjalny, psycholog, zatrudniona na stanowisku adiunkta w Katedrze Dydaktyki i Mediów w Edukacji Wydziału Filozofii i Nauk Społecznych Uniwersytetu Mikołaja Kopernika w Toruniu. Adres e-mail: malfran@umk.pl.

Agata Wołowska - doktor psychologii, zatrudniona na stanowisku adiunkta w Katedrze Dydaktyki i Mediów w Edukacji Wydziału Filozofii i Nauk Społecznych Uniwersytetu Mikołaja Kopernika w Toruniu. Adres e-mail: ataw@umk.pl. 


\title{
RECENZJE
}

\author{
ARLETA SUWALSKA \\ Wydział Nauk o Wychowaniu \\ Uniwersytet Łódzki \\ ORCID ID: https://orcid.org/oooo-ooo3-0713-8451
}

Forum Pedagogiczne

$9(2019) 2$, cz. 2

Wpłynęło: 07.10.2019

Zatwierdzono do druku: 20.11.2019

DOI: $10.21697 / \mathrm{fp} .2019 .2 .46$

\section{Multidimensionality of Contemporary Polish Pedagogy}

[Z. Kwieciński, B. Śliwerski (red.) (2019). Pedagogika. Podręcznik akademicki. Warszawa: Wydawnictwo Naukowe PWN, 1127 s.]

This precisely and accurately updated and fully expanded edition of the bestseller Pedagogika covers the scope of basic knowledge, contemporary pedagogical thoughts and trends. This masterpiece reveals pedagogical approaches that correspond to the global changes in the current world. This outstanding book consists of 50 chapters. The book is recommended as a coursebook for teachers who seek indispensable knowledge about learning and education, presented from different perspectives and dimensions, both theoretically and practically.

The first part of this exceptional book contains 23 chapers. It starts with chapter one Pedagogika jako nauka (Education as science) in which Bogusław Śliwerski discusses concepts and views of pedagogy (education) as theoretical and practical science. The author not only develops pluralistic concept of pedagogy and its ideas but also presents disputes between theories in pedagogy. Śliwerski presents a pluralistic concept of pedagogy, which in the period of the Third Republic of Poland became something obvious and natural. Moreover, the author writes about the crack and radical separation of Polish humanities from monistic, ideologically degraded socialist pedagogy. In addition, he claims that this state will be a lasting achievement of of socio-political transformation.

The second chapter, Edukacja w galaktyce znaczeń (Education in a galaxy of meaning), written by a co-editor, Zbigniew Kwieciński, provides definitions, development phases in education and education barriers for humanity. Moreover, Kwieciński exposes a presentation of discourses, ideologies, paradigms and typologies by Theodore Brameld and William T. O’Neill.

Book's unprecedented approach is especially visible in Historia oświaty $i$ wychowania (History of schooling and education) remarkably prepared by Stefan Wołoszyn, an outstanding master of this educational subdiscipline. Moreover, the chapter Pedagogika pozytywizmu warszawskiego (Pedagogy of Warsaw positivism) prepared by Jacek Kulbaka describes the socio-political situation 
in Poland in the second half of the nineteenth century. It presents the genesis of positivism and thoughts of leading representatives.

The fifth chapter Pedagogika narodowosocjalistyczna (National Socialist pedagogy) written by Adam Fijałkowski and the sixth chapter Polski nurt krytyki totalitaryzmów (Polish criticism of totalitarianism) written by Janina Kostkiewicz extend the readers' knowledge in the field of education (Bildung) in the Third Reich (1933-1945) and criticism of Bolshevism, Italian Fascism and German Nazism. The next chapter, written by J. Kostkiewicz describes Polskie koncepcje i kierunki rozwoju pedagogiki kultury (1918-1939) (Polish concepts and directions of development of pedagogy of culture (1918-1939)). The following pages of this book written by Teresa Hejnicka-Bezwińska broadens the reader's knowledge about Pedagogika socjalistyczna (Socialist pedagogy).

Bogusław Śliwerski in the chapter Teorie wychowania (Theories of Education) conducts intricate theoretical considerations on the theory of education. Śliwerski takes into account relations between theory of education and general pedagogy. In this edition he presents contemporary theories of education (general didactics) with typology of variations in didactics. Readers will find information about Pedagogika wczesnej edukacji (Pedagogy of early-childhood education) perfectly written by Dorota Klus-Stańska.

Pedagogika porównawcza (Comparative pedagogy) was written and explained by Renata Nowakowska-Siuta. The author mentions the most significant topics undertaken in comparative studies. There are revealed such competences as "the ability to communicate in mother tongue and foreign languages, mathematical, scientific and technical competences, creativity and entrepreneurship, social, civic and IT competences with culture awareness and cultural expression." (p. 302)

The chapter Filozofia edukacji (Philosophy of Education) was authored by Rafał Godon who explores the specificity of this pedagogy in the light of philosophical reflection and the methodological aspect of the philosophy of education. The book demonstrates Pedagogika religii (The Religion Pedagogy) and Pedagogika kultury (Pedagogy of Culture) with mutli-dimensional concepts, beginnings and ideas. Both chapters have been created by Bogusław Milerski. Pedagogika społeczna (Social Pedagogy) chapter written by Barbara Smolińska-Theiss and Wiesław Theiss reveals beginnings of social pedagogy, sources, categories and asks questions about its future. Kultura popularna jako czynnik socjalizacji (Popular Culture as a factor of socialization) authored by Zbyszko Melosik fortifies such meanings as: consumption, instant culture, fast pace of life, culture of body and success. Agnieszka Cybal-Michalska writes about Pedagogika młodzieży (Youth pedagogy) as a subject of pedagogical research.

The chapter Andragogika (Andragogy) by Mieczysław Malewski explains the principles of adult education. Moreover, Jacek Pyżalski in the chapter Cyfrowa pedagogika medialna (Digital Media Pedagogy) provides such phenomena as interactivity, digitality and the new media environment. Pedagogika specjalna 
(Special Pedagogy) chapter written by Iwona Chrzanowska draws up the paradigmatic change in defining disability. The author proposes age divisions such as childhood, youth, adulthood and old age of people with disabilities. The chapter Empiryczne badania ilościowe $w$ pedagogice (Empirical quantitative research in pedagogy) prepared by Krzysztof Rubacha equips readers with knowledge on research schemes, methods and quantitative empirical studies. Moreover, the next chapter written by Danuta Urbaniak-Zając increases the reader's knowledge about Empiryczne badania jakościowe w pedagogice (Empirical qualitative research in Education). This chapter arranges the nature of qualitative research, its preparation, research procedures and summary.

The second part of this book contains 15 chapters which include contemporary pedagogical concepts. This is an outstanding work that includes such subsets of Pedagogy as Pedagogika instrumentalna (Instrumental Pedagogy) by T. HejnickaBezwińska, Pedagogika personalistyczna (Personalistic pedagogy) by Marian Nowak, Pedagogika egzystencjalna (Existential Pedagogy) by Janusz Tarnowski, Pedagogika pragmatyzmu (Pedagogy of Pragmatism), Pedagogika postmodernizmu (Pedagogy of postmodernism) by Zbyszko Melosik, Pedagogy of anarchistyczna (Anarchist pedagogy), Pedagogika negatywna (Negative Pedagogy) by B. Śliwerski, Pedagogika krytyczna (Critical pedagogy), Pedagogika międzykulturowa (Intercultural pedagogy) by Tomasz Szkudlarek, Pedagogika emancypacyjna (Emancipation pedagogy), Pedagogika rekonstrukcjonizmu społecznego (Pedagogy of social reconstructionism) by Hanna Kostyło, Pedagogika Gestalt (Gestalt pedagogy) by Wiktor Żłobicki, Pedagogika ekologiczna (Ecological pedagogy) by Agnieszka Gromkowska-Melosik and Utopizm pedagogiczny (Pedagogical utopism) by Rafał Włodarczyk.

The last part consists of 12 chapters which are entitled Pedagogika Reform Edukacyjnych (Pedagogy of educational reforms). The author of three chapters is B. Śliwerski, who discusses the features of Pedagogika waldorfska (Waldorf pedagogy), Pedagogika planu daltońskiego (Pedagogy of the Dalton Plan) and Reformy oświaty $w$ Polsce (Reforms of education in Poland). He pays attention to types of educational reforms in Poland, the scope of educational change, the quality of reforms and to the reforms' implementation.

Wiesław Jamrożek describes Pedagogika "nowego wychowania" (Pedagogy of progressivism) in which the author pays readers' attention to genesis and development of progressivism in Education. Małgorzata Miksza presents Pedagogika Montessori (Maria Montessori's concept of education) and puts emphasis on the role of the teacher in preparing the teaching environment. Z. Melosik reveals the pros and cons of Education in chapter Edukacja a stratyfikacja społeczna (Education and social stratification). The author considers concepts to solve problems with access to higher education. The chapter Szkolne środowisko uczenia się (School learning environment) written by Mariola Chomczyńska-Rubacha associates the organizational culture of the school with the language and patterns of communication in the classroom. 
The definitions, scope and shaping of school culture constitute the chapter Kultura szkoly (School culture) written by Inetta Nowosad. The author describes school efficiency and presents the features of positive school culture. The chapter Proces kształcenia (Educational process) by Bogusława D. Gołębniak discusses the school curriculum, exams and assessment, teaching and learning in the classroom. The chapter Nauczyciel (Teacher) authored by Joanna Madalińska-Michalak presents teacher studies as a subject, including considerations about teacher's duties and professional development. The chapter Agresja i przemoc w szkole (Aggression and violence at school) written by Janusz Szurzykiewicz explains terminological findings and dynamics of aggression and violence at school.

Concepts of education portrayed in this new edition of Pedagogika include involvement of various organizations like the government and institutions that work with families, peers, kindergartens, schools, universities, local communities, associations, organizations, etc. Furthermore, Pedagogika is essential reading for teachers, new academics and anyone who is interested in the educational research. The text is supported by a wealth of pictures, charts, tasks to solve and references. 


\section{Reforming the educational system in Poland: The practice-based perspective}

\section{[A. Szulc (2019). Nowa Szkoła. Szczecin: Wydawnictwo Natuli, 184 pp.]}

This year's events related to the reform of schooling system in Poland, teachers' strikes and the changes in the Cabinet of Minister of Education have resulted in the national debate on the condition of state education in Poland. In view of this situation raise questions whether it is possible to modify schooling in our country and what is the role of school in the constantly changing reality.

An important and interesting voice in the current debate is the book by Anna Szulc Nowa Szkoła (original Polish title; in English: New School; 2019). In this review I will present and analyse the education approach created and successfully implemented by Szulc in her teaching practice through the prism of my parrhesia.

The author is an experienced mathematician in a secondary school. She presents her multiannual observations on ineffectiveness of traditional Prussian approach that prevails in Polish schools e.g. teacher's control over students' behaviour and activity during the lesson, excessive testing, focusing on mistakes and showering students with failing grades, transmission of encyclopaedic knowledge, depriving students of their free, afterschool time, unfriendly atmosphere which hampers learning, inhibiting development of key competences, ignoring the latest discoveries on human brain functioning. The observation by Dorota Klus-Stańska (2012, p. 26) that the role of a teacher and the role of a student are school areas in which traditionalism is deeply-rooted, confirms Anna Szulc's insights.

Having faced all the above drawbacks and impediments in her teaching practice, A. Szulc demonstrates a proactive and innovative approach. She refers in her book to matters nagging many educators: the new role of school, teachers and students in the contemporary world; grading system; homework; misbehaviour and school climate; the need for changes in Polish schools and difficulties in introducing them.

According to the author the contemporary school should become a place that facilitates students' versatile growth and prepares them for life in the future world. The crucial aim of school is thus to educate creative, decisive and responsible young people.

The author emphasises an exceptional role of a teacher in this 'new school'. His main job is to create conditions conducive to student learning. Hence the teacher 
should specialise not only in his school subject but also in psychology, tutoring, etc. He should be a mentor who supports students' development and a guide who shows them the world and universal values. In order to meet all the above requirements the author of the book became herself an open minded and reflective practitioner who continues to improve her methods of teaching. Her ideas correspond to John Hattie's (2003) list of prototypic attributes of a great teacher.

Moreover, the author observes that a redefined role of school and teacher changes the role of the student. Young people should become active participants of their education process. It is related to gaining knowledge e.g. the authors students' participate actively in creative tasks, cooperate with peers, use mnemonic techniques, participate in classroom discussions, etc. It all leads to better understanding and improved retention. But being an active participant also implies getting engaged in setting up classroom rules, giving the teacher feedback on his work, suggesting students' own solutions to problems, deciding on their own grades, etc. Procedures used by the author in everyday school situations can really work wonders - young people gain self-confidence, but foremost, feel responsible for their decisions, education and growth.

As far as grades are concerned, the author admits she does not attach greater importance to them! What matters most is individual student's development. She appreciates even the smallest progress. Thanks to this approach the students and their parents know that gaining knowledge, not good grades, is the aim of their education. The author has created an innovative, student-centred practice: all tests can be retaken many times and the terms are adjusted to a particular student's needs; students decide which grade is final; the teacher is focused on situations when a student has gained knowledge and praises him/her with a grade; mistakes are treated as natural stages in learning and students are not criticised for making them. As a consequence, there is no problem with cheating or demonstrating the right attitude among students, which is observed as a frequent school problem (Klus-Stańska, Nowicka 2006). The procedures implemented by the author have resulted in students' greater motivation, sense of responsibility and empowerment.

Another issue discussed in the book is an ineffective use of the 45-minute-lesson. The author admits that first of all teachers usually do not start the lessons on time, secondly some time is spent on taking the attendance, thirdly, asking an individual student also seems to disturb effective brain processes and steals precious minutes of the lesson as only this particular student is engaged, while the rest of the class are only passive observers. An ineffective use of time results in giving compulsory homework - the illusory remedy for completing the curriculum, which deprives young people of valuable afterschool life. The author of the book has developed a perfect time-managing practice and resigned from setting compulsory homework. Effective education should make use of the most efficient attributes of teaching and learning and eliminate the ones that are time consuming and ineffective e.g. homework (Hattie 2008). 
A natural element of every teacher's work is dealing with students' behaviour. Traditional remedies like behaviour assessment, praises, reprimands, book and financial prizes, ratings, setting straight - Are ineffective and enhance students' external motivation. As an alternative, the author recommends using tested methods derived from the Nonviolent Communication approach. The positive school climate has been achieved by implementing methods that are perfect in their simplicity: being an understanding person, willing to support students, encouraging young people to ask questions, lively students' cooperation, stress-free assessment, student self-grading model, respecting and appreciating mistakes, appropriate relations with other people, misbehaviour as student's call for help, punishments and lack of praises.

The author's everyday teaching practice proves that school in its current format requires vast changes as it does not support students' development. Interestingly, the author aptly identifies the main obstacles to introducing changes: teaching community resistance to changes, ignoring problems, implementing façade and bureaucratic changes, teachers' professional burnout, lack of government support for bottom-up initiatives. Nevertheless, the book presents a positive vision for Polish school provided that curriculum at pedagogic faculties is regularly updated and students are adjusted to existing reality. Secondly, teachers increasingly get inspired by their colleagues' good practice. Last but not least, effective and efficient changes are to be done by practitioners. Not many stakeholders in education understand that only two participants of pedagogical action, a teacher and a student, with their separate, harmonious and synergetic activities of teaching and learning constitute successful school education (Stępkowski 2019).

The book New School is one of few practice-based Polish publications. It is a strong, honest and sensible voice we need in an era of excessive homework, private tutoring and fashion for teaching with the use of new technologies. It presents universal advice intelligible to a wide range of readers - especially teachers and students of pedagogic faculties but also parents, headteachers and even politicians responsible for the education system.

Albert Einstein once said that 'If you can't explain it simply, you don't understand it well enough'. Anna Szulc explains complex school-related problems in a comprehensive and accessible way.

\section{References}

Hattie J., Distinguishing Expert Teachers from Novice and Experienced Teachers. Retrieved from: https://research.acer.edu.au/cgi/viewcontent.cgi?article $=1003 \&$ context=research_conference_2003

Klus-Stańska D. (2012). Wiedza, która zniewala. Transmisyjne tradycje w szkolnej edukacji. Forum Oświatowe, 1(46), 21-40. 
Klus-Stańska D., Nowicka M. (2006). Nauczyciele na drodze awansu zawodowego - między

pozorem a profesjonalizacją. Problemy Wczesnej Edukacji, 1(3).

Hattie J. (2008). Visible Learning. New York: Routledge.

Stępkowski D. (2019). Kształcenie jako dobro pedagogiczne i źródło nierówności edukacyjnej W: Wrońska K. (red.). Dobra edukacji i ich pedagogiczna eksploracja. Kraków: Wydawnictwo Uniwersytetu Jagiellońskiego. 


\section{KRONIKA}

JOANNA PEZKALA

Wydział Pedagogiczny

Forum Pedagogiczne

Uniwersytet Warszawski

9 (2019) 2, cz. 2

Warszawa

Wpłynęło: 30.09.2019

ORCID ID: http://orcid.org/oooo-ooo3-4554-1962

Zatwierdzono do druku: 20.11.2019 DOI: $10.21697 /$ fp.2019.2.48

DARIUSZ STĘPKOWSKI

Wydziat Nauk Pedagogicznych

Uniwersytet Kardynała Stefana Wyszyńskiego

Warszawa

ORCID ID: http://orcid.org/oooo-ooo2-6855-1517

\section{Sprawozdanie z trzeciego spotkania międzynarodowego konsorcjum badaczy zajmujących się edukacją moralno-etyczną, Trnawa 26-28 września 2019 roku}

Miejscem trzeciego spotkania międzynarodowego konsorcjum, w którego skład wchodzą badacze zainteresowani wychowaniem moralnym i kształceniem etyczno-moralnym w Europie Środkowej i Wschodniej, było słowackie miasto Trnawa i tamtejszy Uniwersytet Trnawski. Spotkanie przygotowali i przeprowadzili członkowie Katedry Studiów Edukacyjnych Wydziału Pedagogicznego Uniwersytetu Trnawskiego. W trzydniowych obradach uczestniczyli: Naděžda Pelcová (Wydział Pedagogiczny Uniwersytetu Karola w Pradze, Republika Czeska), Martin Brestovanský, Andrej Rajský, Anna Sádovská i Marek Wiesenganger (Wydział Pedagogiczny Uniwersytetu Trnawskiego w Trnawie, Słowacja), Christo Todorov (Nowy Uniwersytet Bułgarski w Sofii, Bułgaria), Dariusz Stępkowski (Wydział Nauk Pedagogicznych Uniwersytetu Kardynała Stefana Wyszyńskiego w Warszawie, Polska) i Joanna Pękala (Uniwersytet Warszawa, Polska) oraz Dietrich Benner, Roumiana Nikolova i Stanislav Ivanov (Berliński Projekt ETiK, Niemcy).

W imieniu gospodarzy przybyłych powitał A. Rajský. Przedstawił on swoich współpracowników i omówił program trzydniowych obrad. Następnie zabrał głos D. Benner, który wyraził zadowolenie z kolejnego posiedzenia konsorcjum i tego, co udało się wypracować w międzyczasie, a mianowicie: raporty w sprawie stanu szkolnego nauczania etyki w poszczególnych krajach i propozycje nowych zadań testowych. Przy tej okazji mówca przekazał informacje na temat programów europejskich, w szczególności „Horizon Europe”, w ramach których możliwe byłoby sfinansowanie projektu badawczego odnoszącego się do efektów kształcenia 
etyczno-moralnego podczas szkolnych lekcji etyki. Mimo że takie badanie musi obejmować tylko Europę, jednak dzięki trwałej współpracy z naukowcami z Chin i Japonii jego wyniki można będzie odnieść do znacznie szerszego kontekstu.

Potem przystąpiono do pierwszej sesji tematycznej. Martin Brestovanský z miejscowego uniwersytetu zaprezentował badania prowadzone od 2012 roku przez pracowników Katedry Badań Edukacyjnych odnośnie efektywności nauczania etyki w szkołach publicznych na Słowacji. Przedstawił teoretyczny model wychowania prospołecznego i opartą na nim ilościową strategię badawczą. M. Brestovanský wskazał przy tym na trudności, które ujawniły się przy wiązaniu stanowisk teoretyczno-filozoficznego, empiryczno-psychologicznego i pedagogicznego.

W wypracowanej przez trnawski zespół koncepcji centralne miejsce zajmuje kształtowanie cnoty zgodnie ze stanowiskiem personalizmu etycznego. Etapy operacjonalizowania cnoty objęły kilka obszarów problemowych, które sygnalizują następujące terminy: (1) eudaimonia, (2) „prospołeczność”, (3) „działanie praktyczne”, (4) fronesis i (5) „pozytywne emocje”. Na tej podstawie zdefiniowany został przedmiot pomiaru empirycznego. Jest nim charakter, w którym wyodrębnione zostały następujące elementy składowe: (1) zachowania prospołeczne, (2) myślenie etyczne, (3) sprawności noetyczne, (4) cechy charakteru i (5) ukierunkowanie na wartości.

Następnie mówca omówił wyniki przeprowadzonych pomiarów, skupiając się przede wszystkim na danych uzyskanych w odniesieniu do zachowania prospołecznego. Jego zdaniem przełomowe znaczenie dla trnawskich badań ma empirycznie potwierdzona konstatacja, że użyte do tej pory instrumentarium nie niesie ze sobą wiedzy ani na temat rozwoju myślenia prospołecznego uczniów, ani nie daje możliwości jego wspierania przez nauczycieli. Te właśnie braki skłoniły zespół do zwrócenia uwagi na berliński projekt ETiK i badanie ETiK-International.

Po wystąpieniu M. Brestovanský'ego odbyła się dyskusja. Uczestnicy odnieśli się w niej do poszczególnych elementów koncepcji teoretycznej, modelu empirycznego i wyników uzyskanych w badaniach terenowych. Wskazywano na komplementarny charakter obu badań - tego przeprowadzonego w ramach ETiK-u i tego zrealizowanego $\mathrm{w}$ Trnawie. Jedną z korzyści wynikających z porównania obu podejść mogłoby być znalezienie pytań, które w obu projektach pozostały bez odpowiedzi. Konieczność uzyskania na nie odpowiedzi stanowi argument za kontynuowaniem współpracy, która może przynieść korzyści obu stronom.

Po dyskusji gospodarze zaprosili uczestników spotkania na wspólną kolację.

Następnego dnia, w piątek, o godz. 9.30 rozpoczęła się druga sesja tematyczna. Miała za przedmiot szeroko rozumiane nauczanie etyki w szkołach publicznych na Słowacji. Podstawą wystąpienia A. Rajský'ego był referat przygotowany we współpracy z Markiem Wiesengagerem. Ten i pozostałe referaty zostały rozesłane do wszystkich członków konsorcjum dwa tygodnie przed terminem spotkania. Dzięki temu mówca mógł skupić się na wybranych zagadnieniach, które naświetlił i poddał dyskusji. 
Szczegółowe omawianie tego wystąpienia, jak i następnych, wydaje się zbędne, ponieważ ukażą się one w osobnej publikacji. Warte zaznaczenia jest jednak to, że po referacie A. Rajský'ego odbyła się dyskusja, w której uczestnicy zastanawiali się nad procesem przejścia od wychowania moralnego do kształcenia moralno-etycznego. Zauważono, że w każdym z krajów współtworzących konsorcjum można zauważyć zróżnicowanie warunków początkowych, przebiegu i rezultatów tego procesu.

Po dyskusji i przerwie na kawę głos zabrał Christo Todorov, który podjął wspomnianą wyżej problematykę, lecz w odniesieniu do Bułgarii. Również po tym referacie odbyła się dyskusja. Następnie zarządzono przerwę na obiad.

Po przerwie odbyła się trzecia sesja. Składała się z charakterystyk nauczania etyki w dwóch krajach - Polsce i Republice Czeskiej. Pierwszy wystąpił Dariusz Stępkowski, a po nim Naděžda Pelcová. Podobnie jak do tej pory, i po tym wystąpieniu przeprowadzono dyskusję.

Nieco już zmęczonych uczestników spotkania orzeźwiła kolejna tego dnia przerwa kawowa. Po niej głos zabrał D. Benner, który omówił konstruowanie zadań testowych. Swoje wywody zilustrował zadaniami przygotowanymi przez siebie w trzech zakresach tematycznych: tolerancja, uznanie i tożsamość narodowa. Uczestnicy korygowali i proponowali udoskonalenia tych zadań. Po zakończeniu tej sesji udano się na wspólną kolację.

Piąta i ostatnia sesja odbyła się w sobotę przed południem. Przeprowadził ją D. Benner. W jej trakcie zrealizowano trzy zadania: (1) omówiono strukturę przyszłej wspólnej publikacji i sposób pracy nad nią, (2) uzgodniono najbliższe działania odnośnie przygotowania projektu w ramach programu „Horizon Europe” i (3) uzgodniono wstępny program kolejnego posiedzenia konsorcjum, które odbędzie się w Sofii w ostatnim tygodniu czerwca 2020 roku. Po podziękowaniu gospodarzom uczestnicy spotkania udali się w podróże powrotne do swoich krajów. 

DARIUSZ STĘPKOWSKI

Wydział Nauk Pedagogicznych

Forum Pedagogiczne

9 (2019) 2, cz. 2

Uniwersytet Kardynała Stefana Wyszyńskiego

Wpłynęło: 24.10.2019

Warszawa

ORCID ID: http://orcid.org/oooo-ooo2-6855-1517

Zatwierdzono do druku: 20.11.2019

DOI: $10.21697 /$ fp.2019.2.49

\section{Sprawozdanie z międzynarodowej konferencji naukowej pt. "Education in totalitarian ideologies of the $20^{\text {th }}$ century", Smolenice (Słowacja), 17-18 października 2019 roku}

W malowniczo położonym na zboczach Małych Karpat zamku w Smolenicach, w którym mieści się Centrum Kongresowe Słowackiej Akademii Nauk, odbyła się dwudniowa międzynarodowa konferencja naukowa. Po raz trzeci zorganizowali ją pracownicy Katedry Studiów Edukacyjnych Uniwersytetu Trnawskiego w Trnawie pod kierunkiem swojej przełożonej, Blanki Kudláčovej. Od 2013 roku co trzy lata spotykają się tutaj historycy i filozofowie wychowania i kształcenia, żeby wspólnie zastanawiać się i debatować nad kluczowymi problemami pedagogiki. Wydarzeniem, które podsunęło pomysł na temat tegorocznego spotkania, jest obchodzona właśnie 30. rocznica upadku socjalizmu w Europie Wschodniej i Środkowej. W związku z tym organizatorzy zaproponowali przeprowadzenie namysłu nad wychowaniem i kształceniem obecnych w XX-wiecznych ideologiach i ustrojach totalitarnych (Kudláčová, Sádovská [red.]. 2019, s. 8-9). Gwoli kronikarskiej dbałości o szczegóły należy dodać, że współorganizatorami tegorocznej konferencji byli: Central European Philosophy of Education Society (CEUPES) i czasopismo „Historia Scholastica”.

W obradach konferencyjnych uczestniczyło w sumie 29 naukowców z 11 krajów europejskich, a mianowicie: Bośni i Hercegowiny (1), Czarnogóry (1), Czech (3), Hiszpanii (1), Irlandii (1), Łotwy (1), Polski (3), Słowacji (11), Słowenii (1), Węgier (3) i Włoch (1). Wygłoszonych zostało 25 referatów i 2 koreferaty.

Dwudniowe obrady podzielono na pięć sesji, w tym jedną plenarną i cztery sesje w grupach językowych. Podczas uroczystego rozpoczęcia głos zabrała najpierw główna organizatorka - B. Kudláčová, która przywitała przybyłych i przypomniała główny cel spotkania - refleksję nad tym, co wydarzyło się w Europie w XX wieku, nazywanym również „wiekiem totalitaryzmów”. Mówczyni zwróciła uwagę, że smolenickie konferencje nie są epizodycznymi zdarzeniami naukowymi, lecz doprowadziły do nawiązania trwałej współpracy między ich uczestnikami. Współpraca ta wyraża się zarówno w ukierunkowywaniu badań, jak 
i podejmowaniu wspólnych przedsięwzięć naukowych. Ponadto ogromne znaczenie ma, zdaniem B. Kudláčovej, uprzystępnianie w języku angielskim pedagogiki uprawianej w tej części Europy. Temu służy właśnie monografia zbiorowa pt. Education and "Pädagogik" - Philosophical and Historical Reflection, która choć zawiera teksty przedstawione w Smolenicach w 2016 roku, ukazała się dopiero niedawno (Kudláčová, Rajský [red.]. 2019). Blisko dwa lata zajęło bowiem opracowanie językowe. W tym kontekście mówczyni podziękowała Pádraigowi Hoganowi z Narodowego Uniwersytetu Irlandzkiego w Maynooth za mrówczą pracę nad korektą językową wszystkich tekstów składających się na wspomnianą monografię. To uświadamia, jak trudnym i wymagającym zadaniem jest skoordynowanie terminologii pedagogicznej używanej w tradycji kontynentalnej i anglosaskiej.

Jako drugi w części inauguracyjnej wystąpił Ján Pálffy, dyrektor słowackiego Narodowego Instytutu Pamięci, który oprócz kurtuazyjnego pozdrowienia gości, nakreślił w ogólnych zarysach potrzebę dokumentowania śladów ostatniego totalitaryzmu w Europie - komunizmu, aby go eksplorować również od strony naukowej. To zadanie dotyczy w szczególności środowiska nauczycielskiego, które było przez socjalistycznych rządców traktowane wyłącznie instrumentalnie jako zbiorowość krzewicieli „jedynie słusznego ustroju”. Następnie kilka słów do przybyłych gości skierowała dziekan Wydziału Pedagogicznego Trnawskiego Uniwersytetu, Viera Peterková, która życzyła im owocnych obrad.

Po tych wystąpieniach przystąpiono do obrad plenarnych. Złożyły się na nie cztery referaty wygłoszone przez tzw. keynote speakers, czyli głównych prelegentów. Obrady te podzielono na dwie sesje. Pierwszej sesji przewodniczyła B. Kudláčová, która poprosiła o zabranie głosu Ivetę Kestere z Łotewskiego Uniwersytetu Narodowego w Rydze. Tytuł jej referatu brzmiał: Educating the New Soviet Man: Displayed Image and Hidden Resistance. Jego osnową były badania jakościowe przeprowadzone przez autorkę z pomocą etnografii wizualnej, których przedmiotem było blisko 400 fotografii prezentujących uczniów łotewskich szkół podstawowych. I. Kestere przeprowadziła jakościową analizę zgromadzonego materiału pod względem efektywności programu urabiania „nowego człowieka”, który został narzucony szkolnictwu łotewskiemu w okresie okupacji przez Rosję sowiecką. Żeby to sprawdzić, posłużyła się trójwymiarowym modelem ukrytego oporu edukacyjnego, autorstwa polskiej badaczki Anny Babickiej-Wirkus (2018). Wyniki przeprowadzonego badania przekonują, zdaniem I. Kestere, o licznych, jednakże zawoalowanych przejawach sprzeciwu uczniów wobec narzucanego im ideału „nowego człowieka radzieckiego”.

Jako drugi główny prelegent wystąpił wspomniany już powyżej P. Hogan. Tytuł jego wystąpienia brzmiał: The Recurring Conquest of Hearts and Minds: Reflections on Totalitarian Currents in Education. Zanim prowadząca sesję oddała głos mówcy, podziękowała mu za to, że w minionym okresie wspierał naukowców z Europy Wschodniej i Centralnej, którzy po upadku socjalizmu stawiali pierwsze kroki w nieznanym im do tej pory środowisku pedagogów anglosaskich. W odpowiedzi 
na to P. Hogan stwierdził, że po stronie, którą w jakimś sensie na tej konferencji reprezentuje, tzn. tradycji anglosaskiej, wciąż brakuje zainteresowania Europą kontynentalną, a w szczególności jej częścią centralną i wschodnią i myślą pedagogiczną tej części Europy. Głównym powodem takiego stanu rzeczy są różnice terminologiczne i koncepcyjne. Podejmowane przez mówcę działania wynikały stąd, że będąc Irlandczykiem, nie uważa języka angielskiego za swój język ojczysty i być może właśnie to pomogło mu zrozumieć trudności językowe, z którymi muszą się mierzyć pedagodzy z Europy kontynentalnej.

Przedstawiając swój temat, P. Hogan zwrócił uwagę na autorytaryzm, który zadomowił się w kulturze i szkolnictwie zachodnio-europejskim w latach 70. minionego stulecia i niepodzielnie zapanował w nich w latach 90. Polega on jego zdaniem przede wszystkim na pozbawieniu edukacji prawa do rozwijania się według własnych reguł (ang. in its own right) i na narzucaniu jej standardów pochodzących przede wszystkim ze sfery ekonomicznej. Przejawem tego jest ukierunkowanie nauczania szkolnego na wyniki (efekty) i ich empiryczny pomiar. To powoduje obniżenie znaczenia, jakie przykłada się do działania pedagogicznego nauczycieli i wychowawców, a w skrajnych przypadkach całkowite pozbawienie go ważności. Mówca zaproponował, żeby ten stan rzeczy opatrzyć mianem totalitaryzmu pisanego małą literą „t”. Przeciwstawiając się mu, należy podjąć, zdaniem P. Hogena, działania wspierające nauczycieli. Temu właśnie służyły projekty, które w ostatnim czasie realizował na swojej uczelni (np. „Teaching and Learning for 21st Century”). U ich podstaw leżały dwa przeświadczenia, które starał się zaszczepić nauczycielom: po pierwsze, każdy uczeń zdolny jest do rozwoju i uczenia się (ang. nativity) i po drugie, do obowiązków zawodowych nauczyciela należy orientowanie się w różnorodności sposobów nauczania i umiejętne wykorzystywania ich w trakcie nauki szkolnej.

Po wystąpieniach odbyła się dyskusja, a po niej organizatorzy zaprosili na przerwę kawową. Po przerwie przystąpiono do drugiej części obrad plenarnych. Przewodniczyła im nadal B. Kudláčová, która do mównicy zaprosiła Petera Jaška, pracownika Narodowego Instytutu Pamięci z Bratysławy. W wystąpieniu, które zostało zatytułowane Research on the Period of the Communist Regime in Slovakia from the Perspective of the Nation's Memory Institute. Background, State and Perspectives, referent scharakteryzował główne obszary działania reprezentowanej przez siebie instytucji. Po nim prowadząca poprosiła o zabranie głosu Františka Mikloška, działacza opozycyjnego w ramach tzw. tajnego Kościoła na Słowacji w okresie dyktatury socjalistycznej. Przedstawiając mówcę, B. Kudláčová określiła go mianem „żywego świadectwa historii” tamtych czasów. F. Mikloško nakreślił słuchaczom w sposób pełen osobistych refleksji obraz podziemnej działalności, która była prowadzona w środowisku młodzieży akademickiej od drugiej połowy lat 6o. do upadku socjalizmu przez wielu zapomnianych obecnie duchownych i intelektualistów chrześcijańskich. Jego zdaniem, działania te wydały owoce społeczne 
i kulturowe na Słowacji nie tylko w okresie przełomu, lecz także współcześnie są czynnikiem kształtującym życie publiczne.

Tak jak poprzednio po wystąpieniach odbyła się dyskusja. Potem uczestnicy konferencji udali się na obiad. Po nim wznowiono obrady, z tym że odbywały się one już w dwóch grupach językowych: słowacko-czeskiej i angielskiej. Tak obradowano do zakończenia konferencji. Niniejsze sprawozdanie będzie obejmowało tylko wystąpienia wygłoszone w grupie angielskojęzycznej, w której uczestniczył autor.

Pierwszą sesję w tej grupie poprowadził Tomaš Kasper. Poprosił on do mównicy Ingrid Kodelję, która odczytała referat znanego współczesnego filozofa kształcenia ze Słowenii, Zdenko Kodelji pt. Totalitarianism and the Violation of Human Rights. The Case of Slovenia. Po niej do zabrania głosu został zaproszony Vučina Zorić z Czarnogóry, który przedstawił temat: Ideology and Education in Yugoslavia (1945-1990). The Case of Montenegro. Mówca zaproponował najpierw typologizacje okresu, którego dotyczą jego badania, a następnie scharakteryzował każdy z nich z perspektywy indoktrynacji prowadzonej przez centralny rząd w Belgradzie wobec szkolnictwa w Czarnogórze, jednego z krajów wchodzących w skład byłej Jugosławii. Za kontynuację tych rozważań można uznać wystąpienie Snježany Šušnjary z Bośni i Hercegowiny, której referat nosił tytuł The School System in Bosnia and Herzegovina under the Communist Regime. Mówczyni skupiła się w nim na zrekonstruowaniu elementów wychowania ideologicznego, zawartych w podręcznikach szkolnych z okresu dyktatury Josipa Tito. Sesję tę zakończono dyskusją, po której ogłoszona została przerwa kawowa.

Po przerwie przewodniczenie w grupie angielskojęzycznej objął V. Zorić. Otwierając drugą sesję, zaprosił do mównicy Antonio Fco Cnales Serrano z Complutense University w Madrycie. W referacie zatytułowanym Education in the First Two Decades of the Franco Regime przedstawił on działania indoktrynacyjne z wczesnego okresu dyktatury Francisco Franco w Hiszpanii w zakresie szkolnictwa publicznego. Po nim o zabranie głosu został poproszony Paolo Alfieri z Catholic University of Sacred Heart w Mediolanie. Zakres jego referatu obejmował wprawdzie dość krótki okres, tzn. lata 1922-1943, dotyczył jednak interesującego zagadnienia, a mianowicie wprowadzenia obowiązkowych lekcji wychowania fizycznego w szkolnictwie powszechnym we Włoszech, co można traktować jako jeden z elementów indoktrynacji dzieci i młodzieży przez ideologię faszystowską. P. Alfieri zaprezentował temat Physical Education for Italian Children during the Fascist Totalitarian Regime.

Po tych dwóch wystąpieniach odbyła się dyskusja zamykająca pierwszy dzień obrad. W programie wieczornym organizatorzy przygotowali promocję wydanej w tych dniach monografii pod redakcją B. Kudláčovej ([red.]. 2019) i kolację. Promocję rozpoczęło wystąpienie J. M. Rektora Uniwersytetu Trnawskiego, René Bìlika, który podziękował B. Kudláčovej za trzecie z rzędu opracowanie dotyczące szkolnictwa na Słowacji. Niedawno co wydana monografia zwieńcza portretowanie dziejów szkół i nauczycielstwa słowackiego od jego początków w 1918 roku. 
Warto w tym miejscu choćby tylko wymienić dwie pozostałe prace, a mianowicie: Pedagogické myslenie, školstvo a vzdelávanie na Slovensku v rokoch 1939-1945 (Kudláčová [red.]. 2015) i Pedagogické myslenie, školstvo a vzdelávanie na Slovensku od obdobia normalizácie po pád komunizmu (Kudláčová [red.]. 2018).

Po tym przemówieniu zabrał głos jeden z recenzentów opracowania, obecny na konferencji T. Kasper. Również on podkreślił całościowy charakter opracowania B. Kudláčovej, a jednocześnie zwrócił uwagę na to, że dzięki jej staraniom w proces refleksji naukowej włączyło się wielu badaczy ze Słowacji i Czech. Fakt ten zasługuje na podkreślenie, gdyż z perspektywy krajów satelitarnych byłego Związku Socjalistycznych Republik Radzieckich ma to charakter unikatowy. W końcu głos zabrała również redaktorka, która z kolei skierowała uwagę słuchaczy na zadanie podjęte przez historyków - dokumentowania tego, co się wydarzyło w przeszłości. Zadedykowała ona prezentowaną monografię tym wszystkim, których czyny i słowa zostały w książce w jakimś sensie uwiecznione.

Obrady drugiego dnia prowadzono w grupach językowych. Pierwszą sesję grupy angielskojęzycznej poprowadził niżej podpisany. Najpierw poprosił on Zoltána Andrása Szabó i Andrása Németha z Eötvös Loránd University w Budapeszcie o zaprezentowanie swojego referatu. Jego tytuł brzmiał: The Written Communication of Educational Science in Hungary between 1961 and 1990: The Case of Magyar Pedagógia (Hungarian Pedagogy). Przedmiotem analiz były treści artykułów publikowanych w czasopiśmie „Magyar Pedagogia” w okresie 1961-1990. Badacze z pomocą metod ilościowych skonstatowali, że w omawianym czasie największa zmiana dokonała się $\mathrm{w}$ proporcjach między tekstami o charakterze badań podstawowych i aplikacyjnych, na korzyść tych drugich. Innymi słowy: w „Magyar Pedagogia” wraz ze wzrostem w siłę ideologii socjalistycznej coraz częściej publikowano artykuły z obszaru dydaktyki, teorii wychowania i teorii organizacji niż pedagogiki ogólnej i porównawczej. Zdaniem Z. A. Szabó i A. Németha, świadczy to coraz większym stopniu instrumentalnego traktowania wiedzy pedagogicznej w środowisku pedagogów akademickich.

Następnym prelegentem w tej grupie językowej był T. Kasper, który przedstawił referat zatytułowany "And Yet You Were Wrong!" Several Views on Marxist Interpretation and "Rewriting" of the Interwar Democratic Discussion on School Reform in Czechoslovakia in the 1950s. Jak wskazuje tytuł jego wystąpienia, okresem objętym analizą były lata 50. minionego wieku. Czeski historyk wychowania prześledził różne formy sowietyzacji środowiska pedagogicznego i pedagogiki jako nauki w ówczesnej Czechosłowacji.

Trzecią prelegentką w tej sesji była B. Kudláčová. W referacie zatytułowanym Changes in Educational Thought at the Beginning of the Communist Period in Slovakia przedstawiła naukową analizę faktów historycznych, o których poprzedniego dnia opowiadał z perspektywy własnych przeżyć i doświadczeń F. Mikloško. Referentka skoncentrowała swoją uwagę na działaniach edukacyjnych podejmowanych przez tzw. tajny Kościół na Słowacji w środowisku akademickim i ich efektach. 
Czwartym i ostatnim mówcą w tej sesji był Attila Nóbik z University of Szeged. Swoje wystąpienie zatytułował następująco: Changing Roles of History of Education in Hungarian Teacher Training in the 1950s. Referent zwrócił uwage słuchaczy na zmianę rozumienia roli historii wychowania na Węgrzech w latach 50. minionego stulecia. Zmiana ta polegała na zawężeniu problematyki poruszanej w tekstach historycznych wyłącznie do udzielania praktycznych wskazówek metodologicznych pomocnych w pracy pedagogicznej.

Tak jak w poprzednich sesjach po wysłuchaniu referatów odbyła się dyskusja, a potem uczestnicy udali się na przerwę kawową. Po niej odbyła się czwarta i ostatnia sesja, również w grupach językowych. W grupie angielskojęzycznej przewodniczenie jej objęła I. Kestere, która poprosiła o zabranie głosu Katarzynę Wrońską z Instytutu Pedagogiki Uniwersytetu Jagiellońskiego w Krakowie. Prelegentka przedstawiła referat zatytułowany Philosophy in the Service of Ideology in the Communist Period in Poland. The Case of Karol Kotłowski's Philosophical Pedagogy. Mówczyni scharakteryzowała najpierw myślenie totalitarne z pomocą wybranych koncepcji Hannah Arendt, Sergiusza Hessena i Józefa Tischnera, a następnie przeprowadziła wnikliwą analizę tekstów Karola Kotłowskiego. Jej zdaniem, wbrew obiegowym opiniom K. Kotłowskiego należy zaliczyć do części pedagogów, którzy całkowicie świadomie w swojej twórczości naukowej przyjęli rolę krzewicieli ideologii socjalizmu. Jako ostatni w tej grupie wystąpił niżej podpisany. Tytuł jego wystąpienia brzmiał: Integrative or Complementary? 'Archaelogy' of Polish General Pädagogik's Transformations in the Twentieth Century. Skrótowo nakreślił on proces stopniowego zanikania (unicestwiania) pedagogiki ogólnej w polskim dyskursie pedagogicznym w okresie socjalizmu. Za przyczynę tego stanu rzeczy mówca uznał odrzucenie tradycyjnego modelu myślenia pedagogicznego i zastąpienie go myśleniem edukacyjnym. To ostatnie w wydaniu socjalistycznym cechowało się utopijnym dążeniem do całkowitego zintegrowania wychowania i kształcenia, od którego uzależnione było osiągnięcie celów ideologicznych. Patrząc z tego punktu widzenia, utożsamienie wychowania i kształcenia nieuchronnie doprowadziło do konfliktu ze wspomnianym myśleniem pedagogicznym, w którym oba rodzaje czynności zachowują swoją autonomię i wzajemnie się uzupełniają.

Na zakończenie konferencji odbyło się spotkanie wszystkich uczestników. W imieniu organizatorów przybyłym podziękowała B. Kudláčová. Natomiast jej i wszystkim organizatorom wdzięczność wyraził V. Zorić jako reprezentant gości. Konferencję zakończyło pamiątkowe zdjęcie. Wszyscy życzyli sobie ponownego spotkania za trzy lata.

\section{Bibliografia}

Babicka-Wirkus A. (2018). A three-demensional model of resistance in education. „The New Educational Review”. Dostępny na: http://www.educationalrev.us.edu. pl/e52/a3.pdf (otwarto: 14.10.2019 r.) 
Kudláčová B. (red.). (2015). Pedagogické myslenie, školstvo a vzdelávanie na Slovensku $v$ rokoch 1939-1945. Trnava: Vydavatel'stvo Trnavskej univerzity v Trnave.

Kudláčová B. (red.). (2018). Pedagogické myslenie, školstvo a vzdelávanie na Slovensku od obdobia normalizácie po pád komunizmu. Trnava: Vydavatel'stvo Trnavskej univerzity v Trnave.

Kudláčová B. (red.). (2019). Pedagogické myslenie, školstvo a vzdelávanie na Slovensku $v$ rokoch 1945-1989. Trnava: Vydavatel'stvo Trnavskej univerzity v Trnave.

Kudláčová B., Rajský A. (red.). (2019). Education and "Pädagogik" - Philosophical and Historical Reflection. Berlin: Peter Lang.

Kudláčová B., Sádovská A. (red.). (2019). Education in totalitarian ideologies of the 2oth century. Výchova a vzdelávanie v totalitných ideológiách 20. storočia. Book of abstracts. Trnava: Vydavatel'stvo Trnavskej univerzity v Trnave - Vydavatel'stvo Slovenskej akadémie vied. 